Article

\title{
The Influence of Marine Traffic on Particulate Matter (PM) Levels in the Region of Danish Straits, North and Baltic Seas
}

\author{
Szymon Firląg 1,* (D), Mariusz Rogulski ${ }^{2}$ and Artur Badyda ${ }^{2}$ \\ 1 The Faculty of Civil Engineering, Warsaw University of Technology, Lecha Kaczyńskiego 16, \\ 00-637 Warsaw, Poland \\ 2 The Faculty of Building Services, Hydro and Environmental Engineering, Warsaw University of Technology, \\ Nowowiejska 20, 00-653 Warsaw, Poland; Mariusz.Rogulski@pw.edu.pl (M.R.); \\ Artur.Badyda@pw.edu.pl (A.B.) \\ * Correspondence: s.firlag@il.pw.edu.pl; Tel.: +48-605-784-134
}

Received: 20 September 2018; Accepted: 13 November 2018; Published: 16 November 2018

check for updates

\begin{abstract}
The aim of the study was to determine air pollution over the sea surface (North Sea and Baltic Sea) compared to the situation in ports, as well as to examine the impact of ships on the level of particulate matter (PM) concentration. The measurements, made during the two-week cruise of the tall ship Fryderyk Chopin, demonstrated that the principal source of PM emission over the sea surface are passing ships equipped with internal combustion engines, including quite numerous units powered by marine oil. The highest pollution levels were observed in locations distant from the coast, with increasing concentrations when other ships were approaching. During the cruise, at least two places were identified with increased PM concentration $\left(18-28 \mu \mathrm{g} / \mathrm{m}^{3}\right.$ for $\mathrm{PM}_{10}$ and $15-25 \mu \mathrm{g} / \mathrm{m}^{3}$ for $\mathrm{PM}_{2.5}$ ) caused by passing ships. The share of $\mathrm{PM}_{2.5}$ fraction in the general $\mathrm{PM}$ concentration in these places increased from $70-72 \%$ to $82-85 \%$, which means that combustion emission dominated. In turn, measurements made in ports (Copenhagen and Kołobrzeg) showed lower levels of air pollution and indicated a typical variability of the PM concentrations characteristic for land areas. The results confirm the need for determining suitable solutions for sustainable sea transport.
\end{abstract}

Keywords: air pollution; $\mathrm{PM}_{10} ; \mathrm{PM}_{2.5}$; ships emissions; marine traffic; Baltic Sea; North Sea

\section{Introduction}

Clean air is considered to be a fundamental factor important for human health and well-being. The Directive of the European Parliament and the Council of 21 May 2008 on ambient air quality and cleaner air for Europe defines "pollution" as any substance contained in the air which can harm human health and the whole environment. The emitter of air pollution can be both human activities and the natural environment.

Governments and organizations introduce thresholds on the levels of air pollutants to reduce the risk of human disease. The US Environmental Protection Agency (EPA), the World Health Organization (WHO), European Commission (EC) and the European Environment Agency (EEA) declare [1] different limits for these substances in the air (EPA, WHO, EC, EEA) see Table 1.

According to EEA [2] for $\mathrm{PM}_{10}$, i.e., airborne dust particles with equivalent aerodynamic diameter not larger than $10 \mu \mathrm{m}$, the annual average of $40 \mu \mathrm{g} / \mathrm{m}^{3}$ is treated as the threshold for the protection of human health. In addition, a daily concentration of $50 \mu \mathrm{g} / \mathrm{m}^{3}$ should not be exceeded for more than 35 days per year. The average annual threshold for $\mathrm{PM}_{2.5}$, particles with equivalent aerodynamic diameter not larger than $2.5 \mu \mathrm{m}$, is $25 \mu \mathrm{g} / \mathrm{m}^{3}$. The negative impact of pollution, in particular suspended 
particles, on human health has been presented in [3,4]. A comprehensive review of relevant studies along with recommended environmental actions is presented in the WHO Review of evidence on health aspects of air pollution (REVIHAAP) report [5].

Table 1. Limits of selected pollutants in the air defined by the US Environmental Protection Agency (EPA), the European Environment Agency (EEA) and the World Health Organization (WHO) [1].

\begin{tabular}{|c|c|c|c|c|c|}
\hline & \multicolumn{5}{|c|}{ Pollutant } \\
\hline & $\mathrm{CO}$ & $\mathrm{NO}_{2}$ & $\mathrm{O}_{3}$ & $\mathbf{P M}_{2.5}$ & $\mathbf{P M}_{10}$ \\
\hline EPA & $\begin{array}{c}9 \mathrm{ppm}(8 \mathrm{~h}) \\
35 \mathrm{ppm}(1 \mathrm{~h})\end{array}$ & $\begin{array}{c}100 \mathrm{ppb}(1 \mathrm{~h}) \\
53 \mathrm{ppb}(1 \text { year })\end{array}$ & 75 ppb (8 h) & $\begin{array}{c}35 \mu \mathrm{g} / \mathrm{m}^{3} \text { (24 h) } \\
12 \mu \mathrm{g} / \mathrm{m}^{3} \text { (1 year) }\end{array}$ & $150 \mu \mathrm{g} / \mathrm{m}^{3}(24 \mathrm{~h})$ \\
\hline WHO & $\begin{array}{c}100 \mathrm{mg} / \mathrm{m}^{3}(15 \mathrm{~min}) \\
15 \mathrm{mg} / \mathrm{m}^{3}(1 \mathrm{~h}) \\
10 \mathrm{mg} / \mathrm{m}^{3}(8 \mathrm{~h}) \\
7 \mathrm{mg} / \mathrm{m}^{3}(24 \mathrm{~h})\end{array}$ & $\begin{array}{c}200 \mu \mathrm{g} / \mathrm{m}^{3}(1 \mathrm{~h}) \\
40 \mu \mathrm{g} / \mathrm{m}^{3} \text { (1 year) }\end{array}$ & $100 \mu \mathrm{g} / \mathrm{m}^{3}(8 \mathrm{~h})$ & $\begin{array}{c}25 \mu \mathrm{g} / \mathrm{m}^{3}(24 \mathrm{~h}) \\
\left.10 \mu \mathrm{g} / \mathrm{m}^{3} \text { (1 year }\right)\end{array}$ & $\begin{array}{c}50 \mu \mathrm{g} / \mathrm{m}^{3}(24 \mathrm{~h}) \\
20 \mu \mathrm{g} / \mathrm{m}^{3} \text { (1 year) }\end{array}$ \\
\hline EEA & $10 \mathrm{mg} / \mathrm{m}^{3}(8 \mathrm{~h})$ & $\begin{array}{c}200 \mu \mathrm{\mu g} / \mathrm{m}^{3}(1 \mathrm{~h}) \\
40 \mu \mathrm{g} / \mathrm{m}^{3} \text { (1 year) }\end{array}$ & $120 \mu \mathrm{g} / \mathrm{m}^{3}(8 \mathrm{~h})$ & $25 \mu \mathrm{g} / \mathrm{m}^{3}$ (1 year) & $\begin{array}{c}50 \mu \mathrm{g} / \mathrm{m}^{3}(24 \mathrm{~h}) \\
40 \mu \mathrm{g} / \mathrm{m}^{3} \text { (1 year) }\end{array}$ \\
\hline
\end{tabular}

Currently, in the world there is a tendency and social expectation to gather air quality data in real time. The data collected in this way can be used to provide comprehensive spatiotemporal information to supplement available air quality monitoring networks and support the decision-making process and public information [6-9]. In order to increase the spatiotemporal resolution of information on air pollution, researchers try to expand the possibilities of monitoring networks by using, in addition to traditional devices, portable sensors that become more accessible due to advanced technologies, and simultaneously have small sizes and small response times. Thanks to them, information on air quality can be updated in a few minutes or seconds [10]. Low-cost, portable sensors offer mobility, simple configuration, and reconfiguration of measurement nodes. These complementary techniques, using the most recent sensor solutions, are seen as innovative tools for future applications in air pollution monitoring [11,12].

One of the place types where it is difficult to use conventional measuring stations, and where portable measuring devices based on portable sensors can be used, are the areas of the seas and oceans. Pollution in such places does not directly harm human health (except for crews of ships and oil platforms); however, studying their movement allows us to answer questions about the extent of suspended particles spread or about the sources and scale of pollution at sea from drilling platforms and floating ships. Ship emissions are significantly increasing globally and have a remarkable impact on air quality on sea and land. There is a clear need for sustainable sea transport development.

The problem of air pollution over the seas is poorly described in the literature. Some of the few results of measurements made during cruises are presented in $[13,14]$. The authors described measurement campaigns conducted in the summers of 2009, 2010, and 2011 in the western Mediterranean. During the research, sources of pollution were analyzed as well as emissions of substances later included in $\mathrm{PM}_{10}$. It was shown that there was a correlation between the presence of sulfates, vanadium, and nickel in the air and the number of ships passing through. In turn, in [15] research conducted during cruises (also in the Mediterranean Sea) showed that there are alkanes, polycyclic aromatic hydrocarbons (PAHs), and organic compounds associated with suspended solid particles in the air. Significant differences in the concentration and percentage composition of the surveyed groups between the port districts and the full sea and ship routes were identified. Studies have shown that the main source of PAHs in ports and at sea were substances from fuels.

In [16], exhaust gas emissions from ships in the Sea of Marmara and the Turkish Straits were calculated by taking into account main engine, fuel and operations types, navigation times, and speeds of ships. Research showed that the shipping emission in the area was responsible for $25 \%$ of PM emissions and had a higher level than aircraft emissions and rail emissions. A precise maritime emission inventory for ocean-going ships in Hong Kong was developed in [17]. It was obtained that 
the total ship emissions from 37,150 voyages in 2007 were 1035 tonnes, accounting for $16 \%$ of the total emissions of $\mathrm{PM}_{10}$. In the study [18], a comprehensive national-scale ship emission inventory was developed for the first time, with $0.005^{\circ} \times 0.005^{\circ}$ resolution for China, using the bottom-up methodology based on Automatic Identification System (AIS) information from the full year of 2014. Results show that the total estimated maritime emissions for China in 2014 were $1.807 \times 10^{5} \mathrm{t}\left(\mathrm{PM}_{10}\right)$, $1.665 \times 10^{5} \mathrm{t}\left(\mathrm{PM}_{2.5}\right)$. Review [19] identified some serious research gaps, filling of which is needed for better control of vessels emissions, and for decreasing their impacts in China, e.g., ship emission factors calculated for Chinese ships. Some proposition to optimize the operation of the shipping business, such that its influence on air pollution is minimized, without, however, significant increase of its cost, and therefore to protect the entire seaborne trade, is shown in [20]. Authors considered the impacts of three control strategies, including the current emission control area (ECA) design.

The aim of this article is to present the measured concentration of suspended particles $\left(\mathrm{PM}_{10}\right.$ and $\mathrm{PM}_{2.5}$ ) in the air over the North Sea and the Baltic Sea, the influence of PM emission from ships on the air quality over the sea level, and conclusions from the nearly half-month cruise from the port of Edinburgh (GB) to the port of Kołobrzeg (PL) in the second half of September 2017.

\section{Materials and Methods}

In order to be able to perform measurements in places where it is impossible to use conventional measuring stations, researchers from the Warsaw University of Technology built a prototype portable sensor for measuring $\mathrm{PM}_{10}, \mathrm{PM}_{2.5}$, and $\mathrm{PM}_{1}$ concentrations, temperature, and relative humidity. It was created using the Arduino microcontroller, optical DFRobot (https:/ / www.dfrobot.com/index.php? route $=$ product $/$ product\&product_id $=1272 \&$ search $=$ SEN0177\&description=true\#.VWQYrM_tlBc) PM sensor and a humidity and temperature sensor. The standard type of the device offers the possibility of prompt data transfer to the server using a modem and SIM card, but, in the case of measurements described in this paper, due to the lack of the mobile network at sea, the SD memory card was used. During the research, every $60 \mathrm{~s}$ the following data was measured and saved:

- hour and day (Universal Time Coordinated (UTC), based on the data from the built-in Global Positioning System (GPS)),

- geographical location (based on the data from the built-in GPS),

- measured concentrations of $\mathrm{PM}_{10}, \mathrm{PM}_{2.5}$, and $\mathrm{PM}_{1}$,

- temperature and relative humidity.

Measurements performed with the use of optical sensors are not considered as reference methods, but due to the low cost, they offer the possibility to accumulate large amounts of high-resolution data on air quality and therefore undergo intensive testing. Their additional advantage is a high degree of mobility, making it possible without any major problems to perform measurements at sea without the need for complicated apparatus.

Research on PM sensors used in the constructed device have been conducted by scientists from the Warsaw University of Technology from 2015. In order to establish the characteristics of used sensors and the impact of basic meteorological parameters on the quality of data, comparative measurements were made with a reference device as part of the action carried out by the Marshal's Office of the Małopolskie Voivodeship, National Reference and Calibration Laboratory of the Chief Inspectorate of Environmental Protection, AGH University of Science and Technology in Cracow, Cracow Smog Alarm Association, in cooperation with the Regional Inspectorate of Environmental Protection in Cracow and the municipality of the city of Rabka-Zdrój in Poland. The research was carried out at the station of the National Reference and Calibration Laboratory of the Chief Inspectorate of Environmental Protection from 15 February to 15 June 2017, in Rabka-Zdrój. The sensors used also are tested for over two years in a test, field measuring network consisting of 10 devices operating in Nowy Sacz (PL). The conditions in which the devices operate are very diverse. In winter periods, very often there is a very high relative humidity (up to $99.9 \%$ ), fogs, drizzle precipitation, etc., so the humidity 
of the air in which the sensors are tested is very similar to the conditions (especially humidity) at sea. The values of $\mathrm{PM}_{10}$ in which sensors operate sometimes reach $300 \mu \mathrm{g} / \mathrm{m}^{3}$. On the basis of these comparative measurements made in Rabka-Zdrój and verified in Nowy Sącz, sensor characteristics, correction function, and measurement absolute error were determined, which is up to approximately 10\% (for all PM fractions). Percentage errors for used sensors are higher for periods with lower pollution values and lower for periods with high pollution values. In the case of relative values, for low PM concentration levels (daily average up to $20 \mu \mathrm{g} / \mathrm{m}^{3}$ ), the average monthly error values are usually around $2-3 \mu \mathrm{g} / \mathrm{m}^{3}$ (after using correction function taking into account temperature and relative humidity). For high PM concentration levels (daily average over $50 \mu \mathrm{g} / \mathrm{m}^{3}$ ) the average monthly error values are usually around $5-10 \mu \mathrm{g} / \mathrm{m}^{3}$. The need to apply long-term calibration in various atmospheric conditions and other potential ways of using low-cost sensors to supply the existing measurement network have been presented in [21,22].

General disadvantages of low-cost PM sensors are discussed in some studies. This type of sensors is not as precise as the reference methods [23]. Some of them have limited sensitivity and may be affected by many other factors such as relative humidity. Often sensors from the same manufacturer and from the same series give different measurement values [24]. Many of these sensors do not contain information about the conditions in which the calibration was carried out (if it has been carried out), procedures related to the maintenance of quality or descriptions when the sensors can generate inaccurate readings. For these reasons, it is necessary to examine and calibrate used sensors for a long time, especially in situations affecting deviations of low-cost sensor readings-such as during high relative humidity, inversion, and windless weather [25].

The PM measurements with the use of the designed device were conducted during a cruise on the STS (sail training ship) Fryderyk Chopin sailing ship as part of the tutorial seminar of the Warsaw University of Technology on the Wave. The tutorial was organized by the Warsaw University of Technology and targeted to its students. The subject of the 2017 edition was "Tools and challenges for contemporary engineers". During the seminar, students also measured the elements of the ship using fiber optic sensors, accelerometers and electrofusion strain gauges.

The STS Fryderyk Chopin (Figure 1) is a Polish brig-rigged sail training ship. It was planned by Polish naval architect Zygmunt Choren, named in honour of the Polish composer Fryderyk Chopin. The ship was built in the Dora Shipyard, Gdańsk, Poland, and launched in the year 1992.

The measuring device was placed at the beak of the ship, and the base of the foremast (Figure 1), around $1.7 \mathrm{~m}$ over the deck. The chosen location minimized the effect of the ship's own emissions on the measurement. All the exhausts, i.e., from the kitchen, power generator, or engine, were behind the sensors. The tall ship mostly sailed into the wind or with a side wind, therefore leaving the sensors freely perfused by air coming directly from the sea. Most of the cruise was on the sails, and the engine was used occasionally. The power generator and engine exhaust were emitted through a chimney located on the mainmast at the waist. The chimney's height was $32 \mathrm{~m}$ from the deck level. 


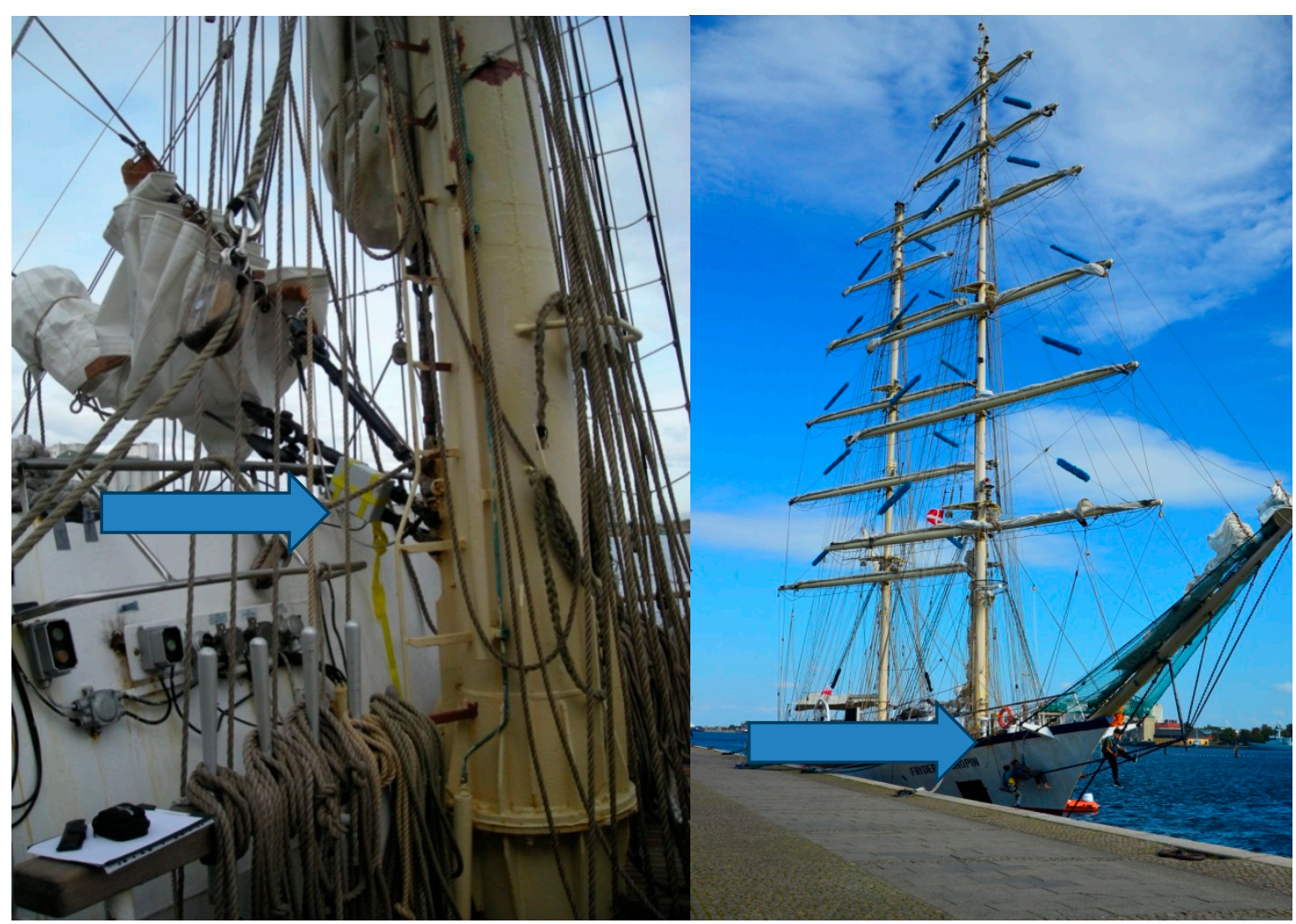

Figure 1. Measuring device placement at the base of the foremast at the beak of the tall ship.

\section{Results and Discussion}

\subsection{PM Concentrations in the Region of Danish Straits and North and Baltic Seas}

The cruise took place between 16 and 30 September 2017. It began in Edinburgh port in the UK and finished in Szczecin port, Poland. During the cruise, the tall ship stopped in two ports-Copenhagen (Denmark) and Kołobrzeg (Poland). The measurements began on 17 September at 16:00 and stopped on 29 September at 20:00. The tall ship set sail in Edinburgh at 14:00 on 18 September and began its cruise through the North Sea towards of the Danish straits. After sailing through Skagerrak and Kattegat, it sailed to Copenhagen at 17:30 on 24 September. It stayed in the port until 26 September 8:15. Next, through the Baltic Sea, it sailed to the Kołobrzeg port in Poland and reached it on 28 September at 8:00. It left the port on 29 September at 18:00 and sailed towards Szczecin. The measurement of particles concentration was stopped an hour after leaving the Kołobrzeg port. The average hourly concentration of $\mathrm{PM}_{10}, \mathrm{PM}_{2.5}$, and $\mathrm{PM}_{1}$ particles throughout the whole cruise and the change of the particle's fraction quota are shown in Figure 2.

In Edinburgh, where the cruise began, typical levels of average yearly $\mathrm{PM}_{10}$ concentration levels were $11 \mu \mathrm{g} / \mathrm{m}^{3}$ (average in 2016, [26]). The measuring period started from very small, as far as city conditions are concerned, values of PM concentrations. The registered $\mathrm{PM}_{10}$ concentrations of $2-4 \mu \mathrm{g} / \mathrm{m}^{3}$ are unattainable for many cities in Europe. With a relatively low temperature (around 11-14 ${ }^{\circ} \mathrm{C}$ ), we could have expected much higher levels of pollution (coming from heating for instance). On 18 September between 6:00 and 10:00, we can see a gradual increase of pollution (up to $4-5 \mu \mathrm{g} / \mathrm{m}^{3}$ $\mathrm{PM}_{10}$ and $2 \mu \mathrm{g} / \mathrm{m}^{3} \mathrm{PM}_{2.5}$ ) - the probable cause is the change in the wind direction, again wind blew from the mainland. The obtained values were compared with those obtained using devices belonging to local authorities. As the reference station was chosen the one closest to the port-Edinburgh St. Leonards. The values measured at Edinburgh St. Leonards (https:/ / uk-air.defra.gov.uk/data/data selector) station were only slightly higher than those measured with our device; however, it should 
be remembered that the reference station is located in the city center, which means that the values recorded in the port can be expected to be lower than at Edinburgh St. Leonards station.

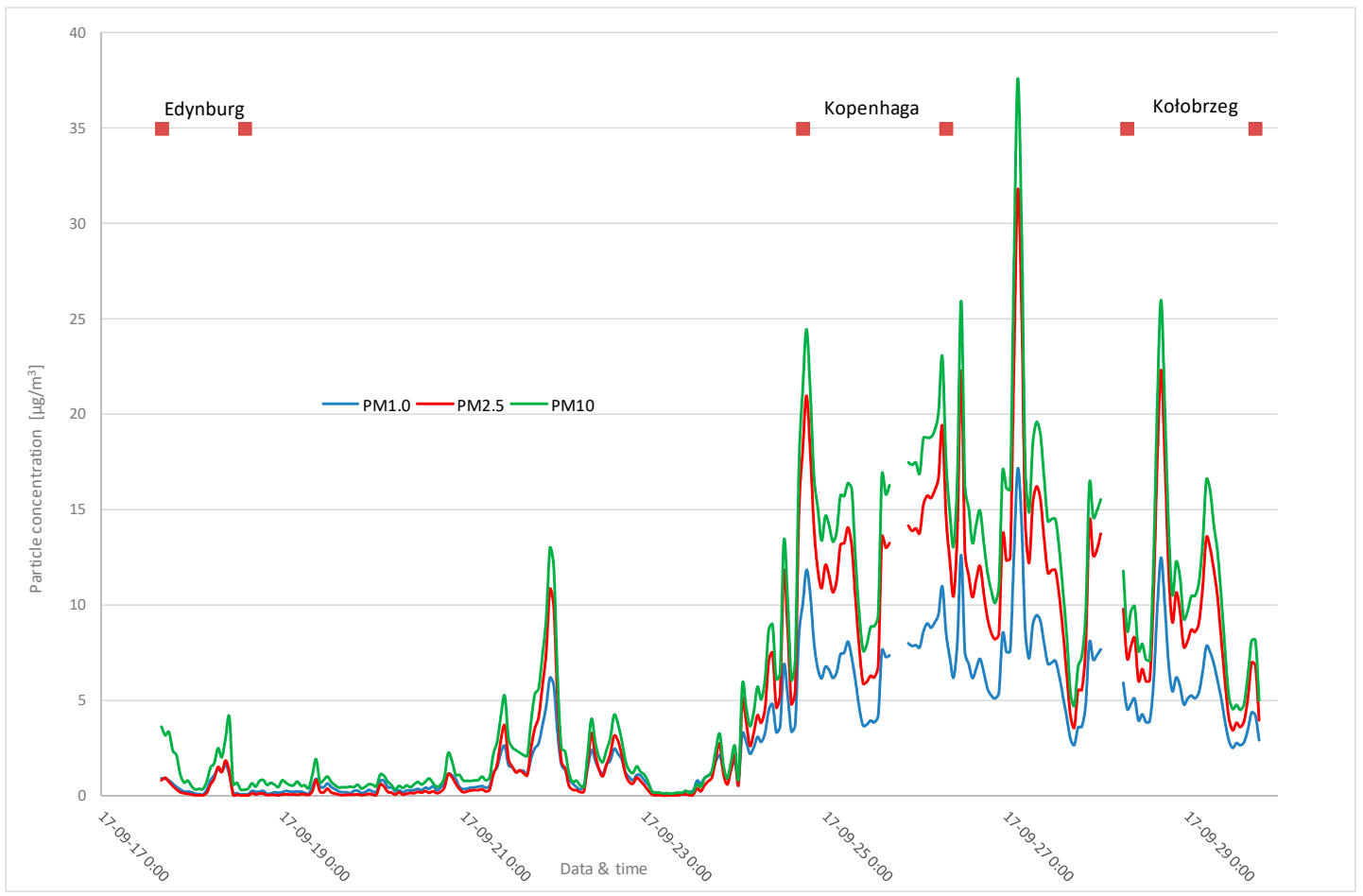

Figure 2. Average hourly concentration of $\mathrm{PM}_{1}, \mathrm{PM}_{2.5}$, and $\mathrm{PM}_{10}$ particles $\left(\mu \mathrm{g} / \mathrm{m}^{3}\right)$ throughout the whole cruise with marked stops in ports.

A very clean period was sustained throughout the cruise through the North Sea until 8:00 on 21 September (Figures 3 and 4). Average $\mathrm{PM}_{10}$ concentrations for this whole period were $0.76 \mu \mathrm{g} / \mathrm{m}^{3}$ and $0.2 \mu \mathrm{g} / \mathrm{m}^{3}$ for $\mathrm{PM}_{2.5}$. Later, the average pollution slightly increased to $2.88 \mu \mathrm{g} / \mathrm{m}^{3}$ in the case of $\mathrm{PM}_{10}$ and $1.75 \mu \mathrm{g} / \mathrm{m}^{3}$ for $\mathrm{PM}_{2.5}$. The distance from land was about $100 \mathrm{~km}$, the wind was coming from the full sea. A similar level of pollution was sustained for around $10 \mathrm{~h}$.

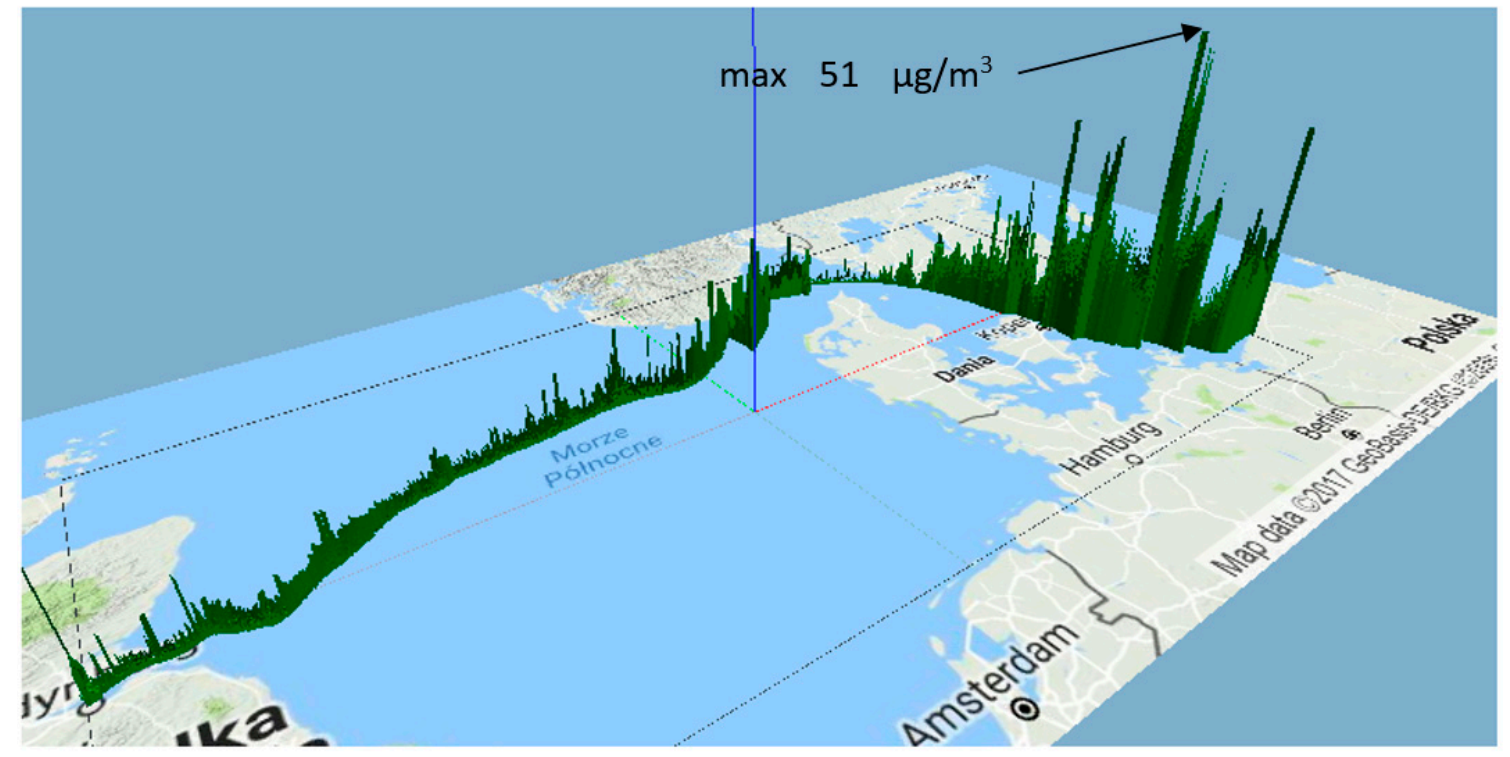

Figure 3. 3D graph of temporary $\mathrm{PM}_{10}$ concentration $\left(\mu \mathrm{g} / \mathrm{m}^{3}\right)$ applied on the cruise path. 


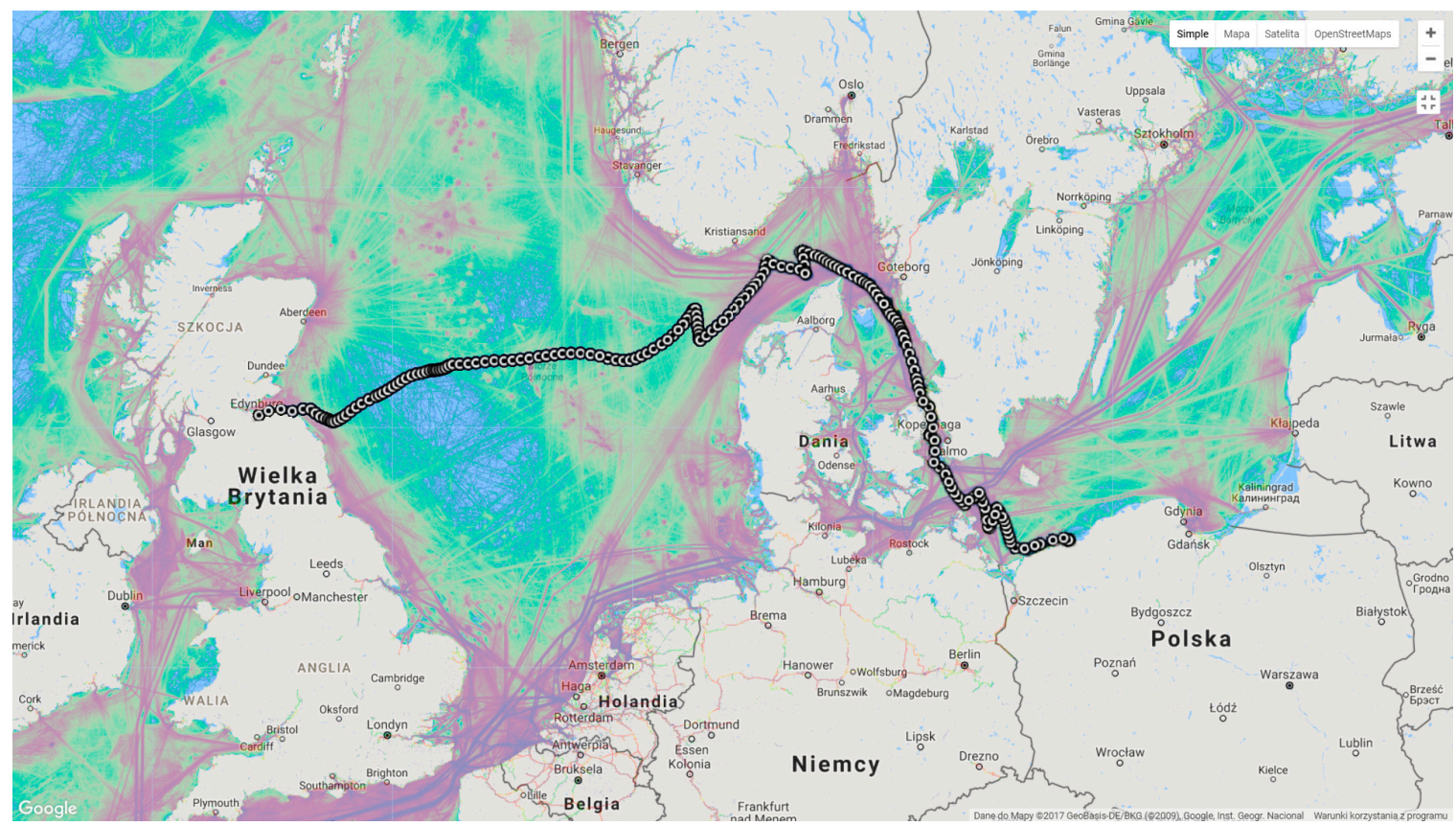

Figure 4. Tall ship path on a background showing shipping traffic intensity and main shipping lanes (source: marine traffic).

Around 23:00-24:00 on 21 September, an increase in concentration can be observed. Average $\mathrm{PM}_{10}$ and $\mathrm{PM}_{2.5}$ concentrations for this hour were 13 and $10 \mu \mathrm{g} / \mathrm{m}^{3}$, respectively. Shipping lane analysis, performed with the help of the marine traffic data, shows that the tall ship was close to the main lane travelled by numerous ships (to or from the Danish Strait)-Figures 5 and 6 . After crossing the lane, STS Fryderyk Chopin started to recede from the different ships; therefore, the pollution level decreased to about $1.5 \mu \mathrm{g} / \mathrm{m}^{3}$ of $\mathrm{PM}_{10}$. About 4:00 on 22 September, the ship was more or less in the middle of the strait between Norway and Denmark. The influence on PM concentration of other ships, or of the land, could not be seen because $\mathrm{PM}_{10}$ concentrations were close to $0 \mu \mathrm{g} / \mathrm{m}^{3}$.

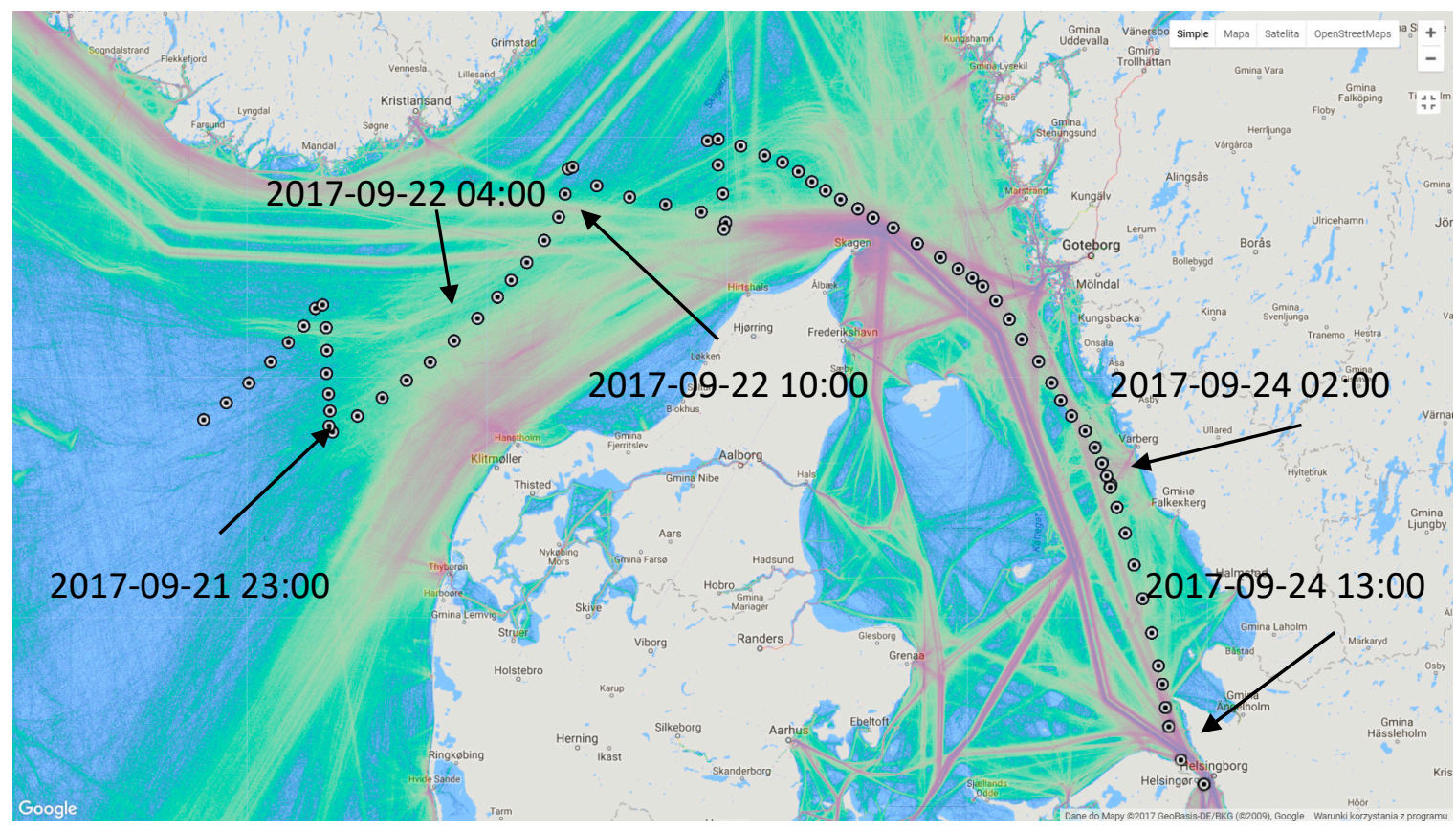

Figure 5. Tall ship route from 9:00 on 21 September until 14:00 on 24 September on a background showing shipping traffic intensity and main shipping lanes (source: marine traffic). 


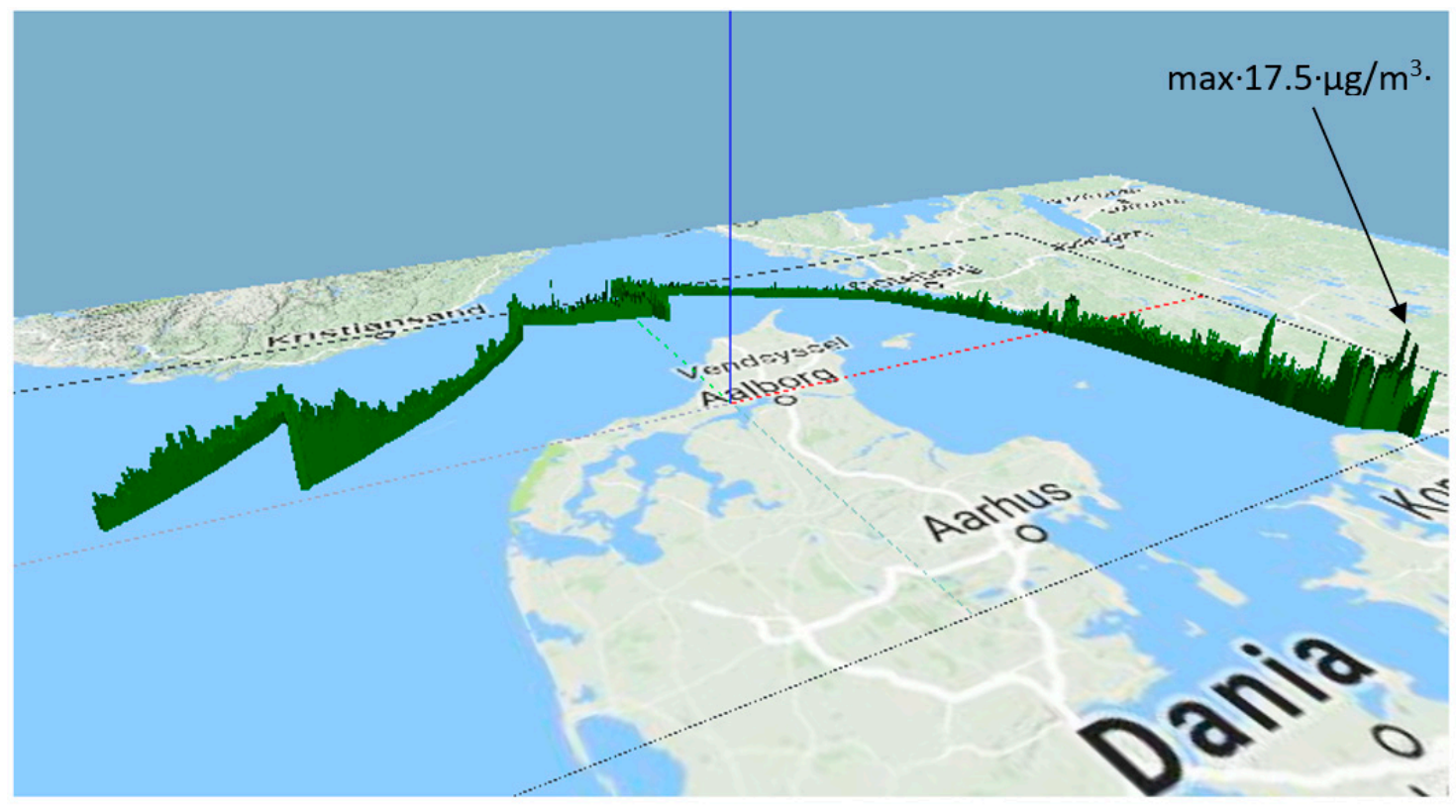

Figure 6. 3D graph of time series of $\mathrm{PM}_{10}$ concentrations from 9:00 on 21 September until 14:00 on 24 September placed upon the tall ship route.

An insignificant increase took place around 10:00 on 22 September (up to $8 \mu \mathrm{g} / \mathrm{m}^{3} \mathrm{PM}_{10}$ and $7 \mu \mathrm{g} / \mathrm{m}^{3} \mathrm{PM}_{2.5}$ ). The ship was closer to Norway, and possibly the temporary increase was caused by cutting through the Hirtshals-Kristiansand water route. For the next few hours, despite nearby land, the concentrations kept a relatively low level-1.5-2 $\mu \mathrm{g} / \mathrm{m}^{3} \mathrm{PM}_{10}$. The measurements show that the air in the mideastern part of Skagerrak during the journey was very clean. The analysis of shipping lanes and water traffic in the service marine traffic shows that the ships are using its South part, bypassing a headland, next to which is the Danish town of Skagen. The obtained low levels of particle concentrations, despite the nearby land, and highly trafficked water routes can be caused by two reasons:

- Presence of a stronger wind, $11-14 \mathrm{~m} / \mathrm{s}$ - during the other part of the cruise, the wind was around $3.5-8.0 \mathrm{~m} / \mathrm{s}$,

- The direction of wind blowing, which at the time changed from south to northeast- the wind came from Sweden (Figure 7).

The stronger wind had effectively removed suspended particles, coming from neighbouring ships and land sources. The wind direction had also caused the pollution from the water traffic to travel in the direction of Denmark, instead of the tall ship. 


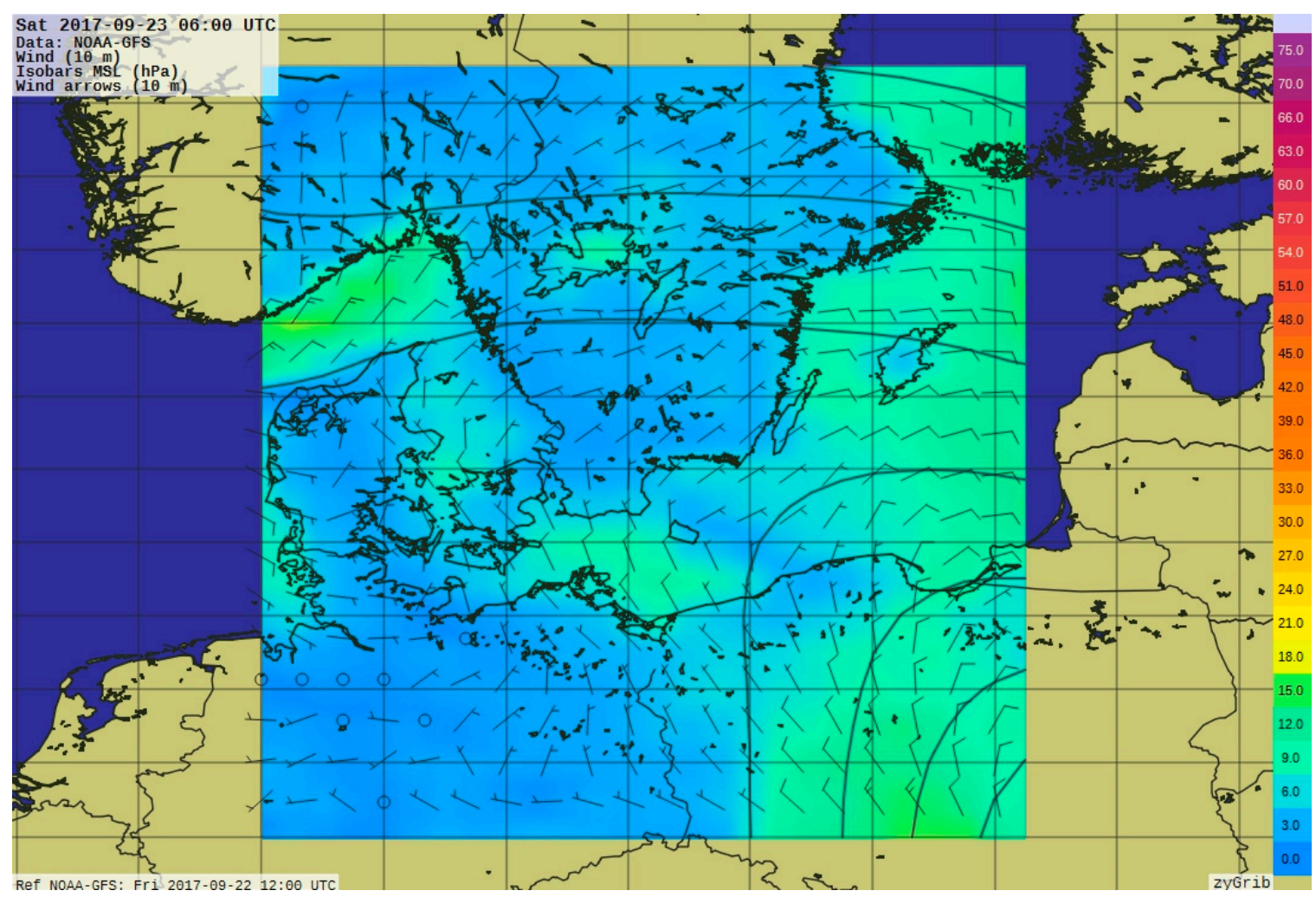

Figure 7. Forecast of wind strength and direction at 6:00 on 23 September 2017 based on the National Oceanic and Atmospheric Administration - Global Forecast System (NOAA-GTS) data from 12:00 on 22 September 2017.

The increase in concentration (to $7 \mu \mathrm{g} / \mathrm{m}^{3} \mathrm{PM}_{10}$ and $5 \mu \mathrm{g} / \mathrm{m}^{3} \mathrm{PM}_{2.5}$ ) occurred only around 2:00 on 24 September, when the ship was about $11 \mathrm{~km}$ away from Swedish land. Even greater increase in particle concentrations appeared at around 13:00 on 24 September. Between 13:00 and 14:30, average concentration of $\mathrm{PM}_{10}$ was $13 \mu \mathrm{g} / \mathrm{m}^{3}$ and $11.6 \mu \mathrm{g} / \mathrm{m}^{3}$ for $\mathrm{PM}_{2.5}$. The position of the tall ship was at that time close to the Copenhagen-Oslo route.

A couple of kilometres from the centre of Copenhagen (at 17:00 on 24 September: $17.5 \mu \mathrm{g} / \mathrm{m}^{3} \mathrm{PM}_{10}$ and $14.5 \mu \mathrm{g} / \mathrm{m}^{3} \mathrm{PM}_{2.5}$ ), the next increase was spotted. After entering the port, a cycle of concentration changes adopted evident "land" characteristics. In many cities, the typical daily course of variations in PM concentrations, especially during lower temperatures, looks like the lowest values are observed before noon, and the highest in the evening or night. In Copenhagen, the concentrations reached a maximum in the late afternoon (hourly averages: $25 \mu \mathrm{g} / \mathrm{m}^{3} \mathrm{PM}_{10}, 21 \mu \mathrm{g} / \mathrm{m}^{3} \mathrm{PM}_{2.5}$ ), and a minimum in the early morning (hourly averages: $7.5 \mu \mathrm{g} / \mathrm{m}^{3} \mathrm{PM}_{10}, 5.9 \mu \mathrm{g} / \mathrm{m}^{3} \mathrm{PM}_{2.5}$ ). After leaving the Copenhagen port on 26 September (Figures 8 and 9), the measured concentrations, after an initial decrease, later underwent large fluctuations. First, a local, relatively large maximum $\left(33 \mu \mathrm{g} / \mathrm{m}^{3} \mathrm{PM}_{10}\right.$, $27 \mu \mathrm{g} / \mathrm{m}^{3} \mathrm{PM}_{2.5}$ ) was noted at 11:45. The ship was then about $10 \mathrm{~km}$ from the Danish coast.

On 27 September at about 2:30, the maximum concentration of $\mathrm{PM}_{10}$ was noted during the whole cruise (Figure 8)-51 $\mu \mathrm{g} / \mathrm{m}^{3} \mathrm{PM}_{10}$ and $44 \mu \mathrm{g} / \mathrm{m}^{3} \mathrm{PM}_{2.5}$. The tall ship was then $25 \mathrm{~km}$ from the nearest land, so much further than during the past hours or other cruise days. The average wind speed was around $6 \mathrm{~m} / \mathrm{s}$ direction SE. The distance to the land in the direction of the blowing wind was over $180 \mathrm{~km}$. It is in an area where the route leading from the Baltic Sea towards ports in northern Germany runs (Figure 8). A high level of pollution was sustained for around $2 \mathrm{~h}$ (hourly averages: $37 \mathrm{\mu g} / \mathrm{m}^{3} \mathrm{PM}_{10}$ and $32 \mu \mathrm{g} / \mathrm{m}^{3} \mathrm{PM}_{2.5}$ ). From vessel traffic data and observation of PM concentrations, it appears that emissions from ships are a key source of air pollution with particles in this region (Figure 8). The traffic density in this area is about 22 thousand routes per $0.02 \mathrm{~km}^{2}$ per year (source: marine traffic). 


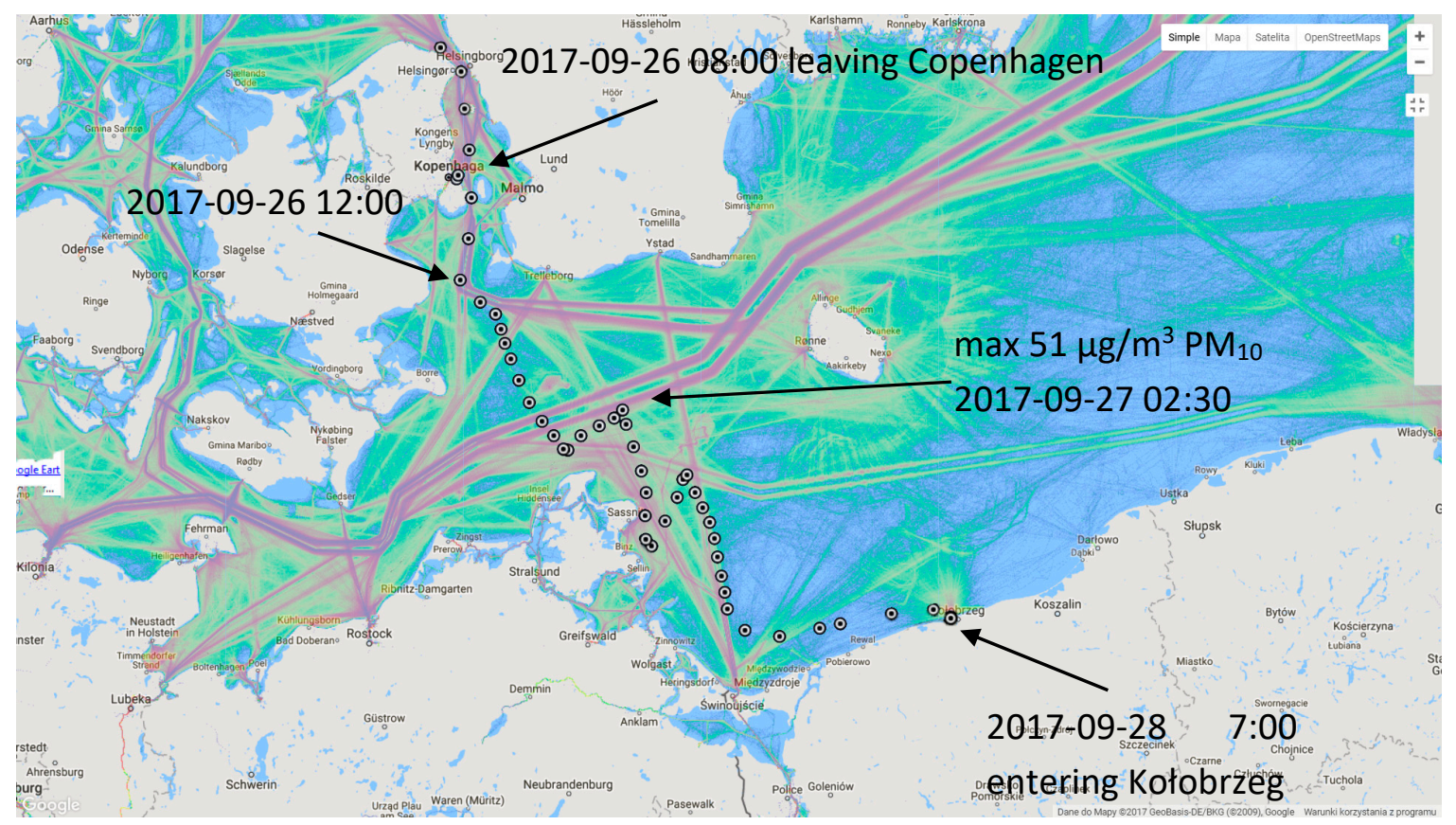

Figure 8. Tall ship path from 15:00 on 24 September to 19:00 on 29 September with the background showing traffic intensity and main shipping lanes (source: marine traffic).

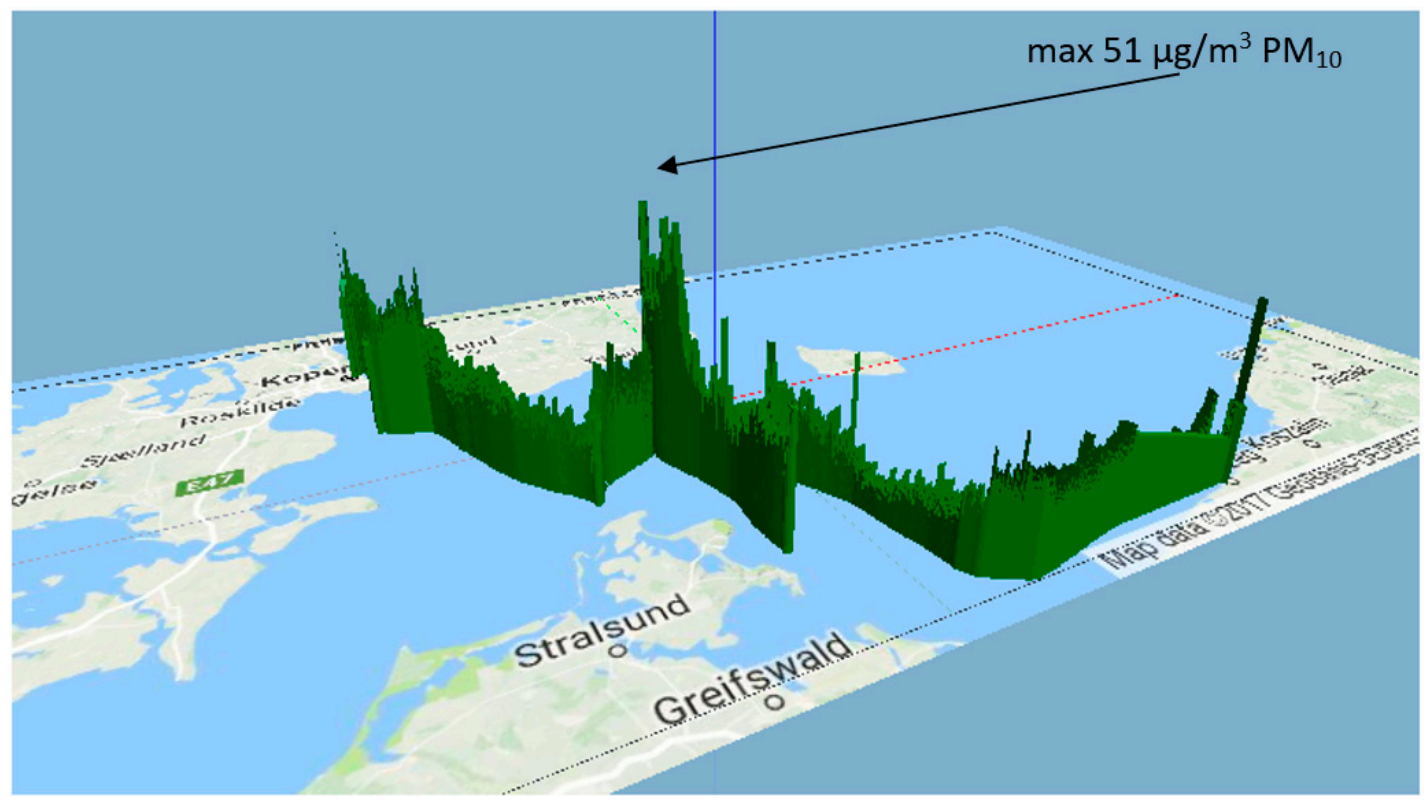

Figure 9. 3D graph of temporary concentration of $\mathrm{PM}_{10}\left(\mu \mathrm{g} / \mathrm{m}^{3}\right)$ from 15:00 on 24 September until 19:00 on 29 September placed upon the cruise path.

A decline in pollution concentration by nearly half happened after sailing the next $5 \mathrm{~km}$, about $20 \mathrm{~km}$ away from the German island Rugia. Similar levels of pollution sustained until the afternoon hours on 27 September. As the tall ship moved away from Rugia in the southeast direction, the concentration of particles decreased even more, reaching concentrations in the range of $5-10 \mu \mathrm{g} / \mathrm{m}^{3}$ $\mathrm{PM}_{10}$. The next increase, to around $10-15 \mu \mathrm{g} / \mathrm{m}^{3} \mathrm{PM}_{10}$ and $8-10 \mu \mathrm{g} / \mathrm{m}^{3} \mathrm{PM}_{2.5}$, happened in the late evening hours of the same day when the ship was about $30 \mathrm{~km}$ from the Polish coast. Such a level of concentration was sustained until the morning hours of 28 September when the ship was directed towards a port in Kołobrzeg. During a stay in the port, changes in concentration were again more 
characteristic of land areas (maximum was noted at around 16-17), analogically to the situation in the Copenhagen port.

\subsection{Pollution Migration and Sources}

The undertaken measurements allow for an analysis of pollution migration. Figure 10 shows the dependence of the average $1 \mathrm{~h} \mathrm{PM}_{10}$ concentration on the distance from land. The distance was calculated in the direction of the blowing wind. For example, if it was blowing from the east, the nearest land on the east was located and distance between ship and the land measured. In order to make the calculation precise, the wind circulation was also included. The analysis was based on weather data from NOAA-GTS forecast and notes from the cruise log shared by the captain of the tall ship. The GTS (Global Forecast System) is a global numerical weather prediction system supported by the American NOAA - National Oceanic and Atmospheric Administration. The weather data were downloaded from the NOAA-GTS server during the cruise and read in zyGrib tool. Sample data showing the strength, direction, and wind rotation are shown in the Figure 7. This information allowed for the determination of wind direction and its circulation in the region of the cruise. The wind speed during the cruise was between 2 and $14 \mathrm{~m} / \mathrm{s}$. The main aim of the analysis was to check if the recorded emission peaks can be caused by land sources. For example, maximum concentration of $\mathrm{PM}_{10}$ was noted on 27 September at 02:30 when the tall ship was $25 \mathrm{~km}$ from the nearest land (Germany). The distance to the land (Poland) in the direction of the blowing wind was over $180 \mathrm{~km}$. The nearest air quality monitoring station in Poland is located in Koszalin (http:/ / powietrze.wios.szczecin.pl/danepomiarowe/automatyczne/stacja/5/parametry/wszystkie). The recorded concentration of $\mathrm{PM}_{10}$ on 26 September at 19:00 (the average wind speed was $7 \mathrm{~m} / \mathrm{s}$ so the distance of $180 \mathrm{~km}$ was defeated in about $7.5 \mathrm{~h}$ ) was equal to $38.9 \mu \mathrm{g} / \mathrm{m}^{3}$. This example shows that increase of $\mathrm{PM}_{10}$ concentration was most likely caused by ship emission.

What is interesting, two areas of high concentration can be observed. The first one is in the distance from 0 to about $90 \mathrm{~km}$ with the highest level of $\mathrm{PM}_{10}$ just above $25 \mu \mathrm{g} / \mathrm{m}^{3}$. The high level of particulate matter concentrations could have been influenced by land sources, e.g., from ports or cities when the tall ship was nearby land or mooring. It took place in the Danish straits and the Baltic Sea. Another source of emissions could be passing ships in such places where the route of the STS Fryderyk Chopin was close to, crossing or even following, the main lane travelled by numerous ships.

The second area of high concentrations can be spotted in the distance from 140 to $220 \mathrm{~km}$ from the land. The highest level of $\mathrm{PM}_{10}$ was about $38 \mu \mathrm{g} / \mathrm{m}^{3}, 180 \mathrm{~km}$ from the land. The onshore sources of PM emission were replaced by the emissions arising from ships. This claim could be confirmed by the fact that such locations were spotted at a considerable distance from land-about 140-220 km, where the influence of land-based emissions sources is rather negligible. The location of areas with high $\mathrm{PM}_{10}$ concentrations indicates that the main source of emissions were probably ships with marine diesel engines (Figure 11). This thesis was confirmed in a detailed analysis of measurement data, presented in the following part of the article. The accumulation of pollutants from ships relatively close to the land is confirmed by the authors [27] —nearly $70 \%$ of ship emissions occur within $400 \mathrm{~km}$ of coastlines. It is causing air quality problems through the formation of ground-level ozone, sulphur dioxide emissions, and PM in coastal areas and ports with heavy traffic. 


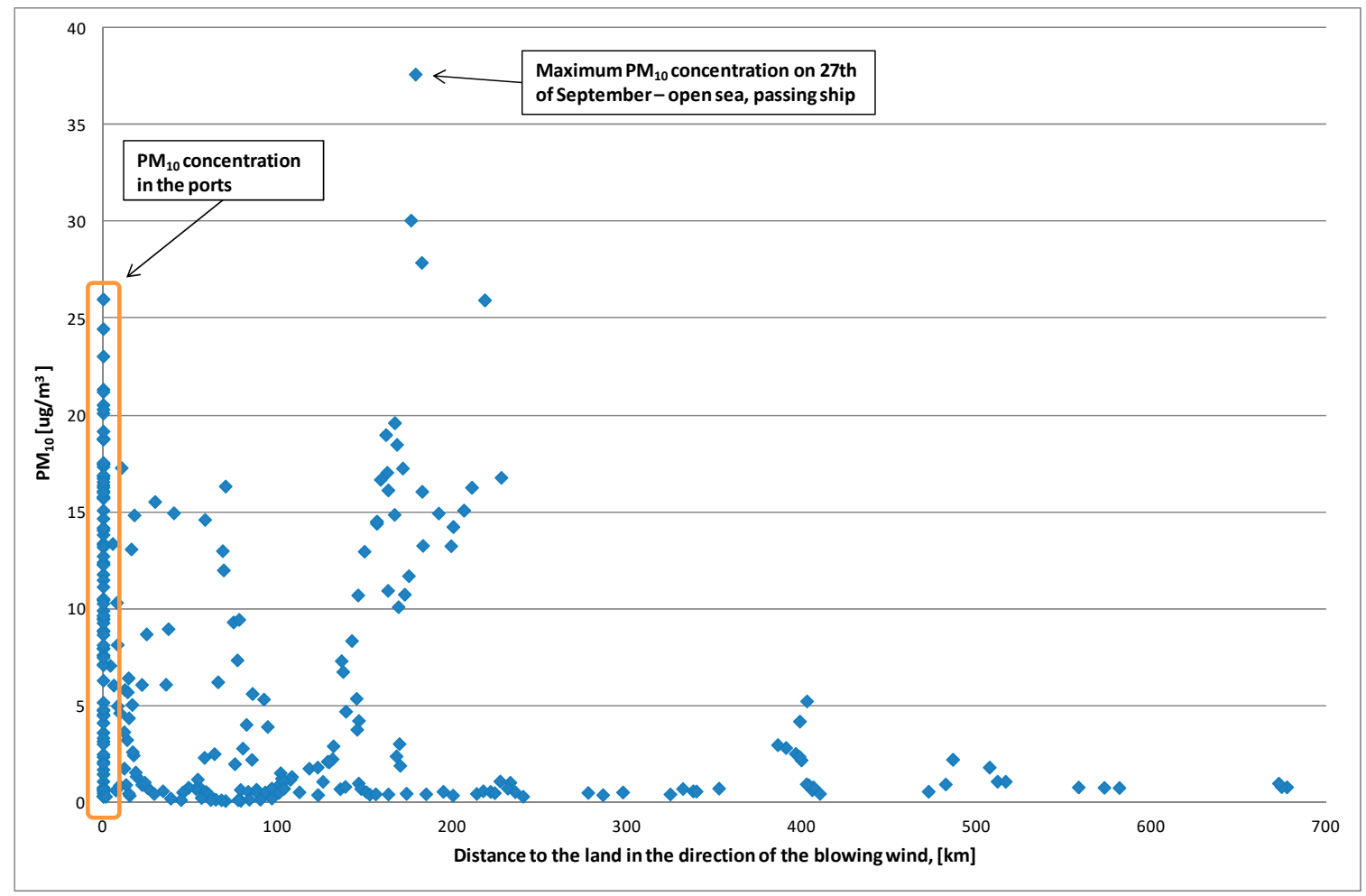

Figure 10. Dependence of average $1 \mathrm{~h} \mathrm{PM} 10$ concentrations $\left(\mu \mathrm{g} / \mathrm{m}^{3}\right)$ on the distance to the land $(\mathrm{km})$ in the direction of the blowing wind.

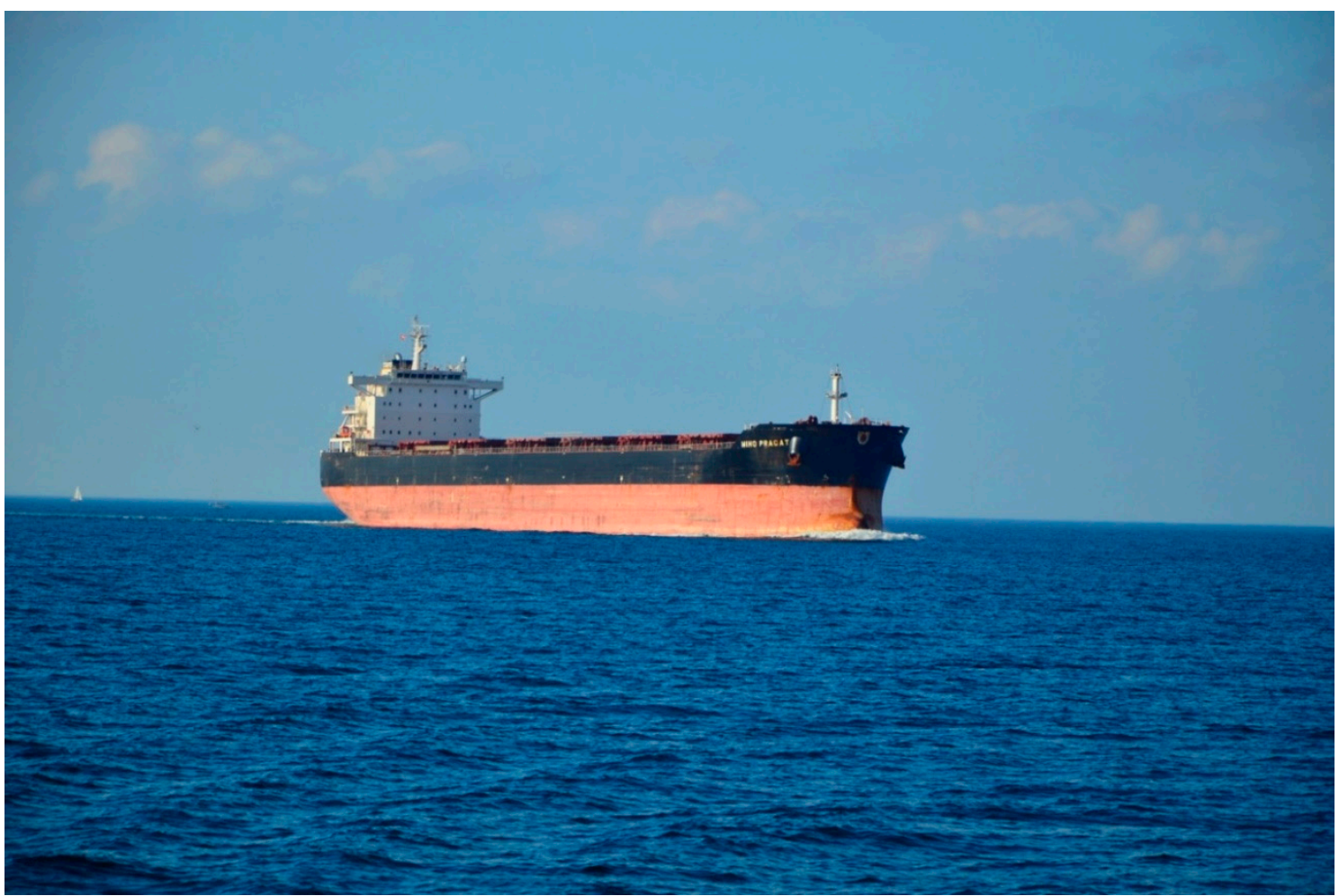

Figure 11. The oil tanker passing the tall ship between 16:55 and 17:15 on 24 September 2017.

The influence of ships' emissions was confirmed by detailed analysis of temporary PM concentrations and weather conditions. One of the increases was spotted a couple of kilometres from the centre of Copenhagen on 24 September 2017 between 16:25 and 17:25 (Figure 12). The tall ship 
was using its engine (the results do not show the influence of its own emission) and preparing to enter the port. The oil tanker, going in the same direction, was passing the tall ship between 16:55 and 17:15 from the east site (Figure 11). This situation is very clearly visible in the graph showing the change of particle concentration.

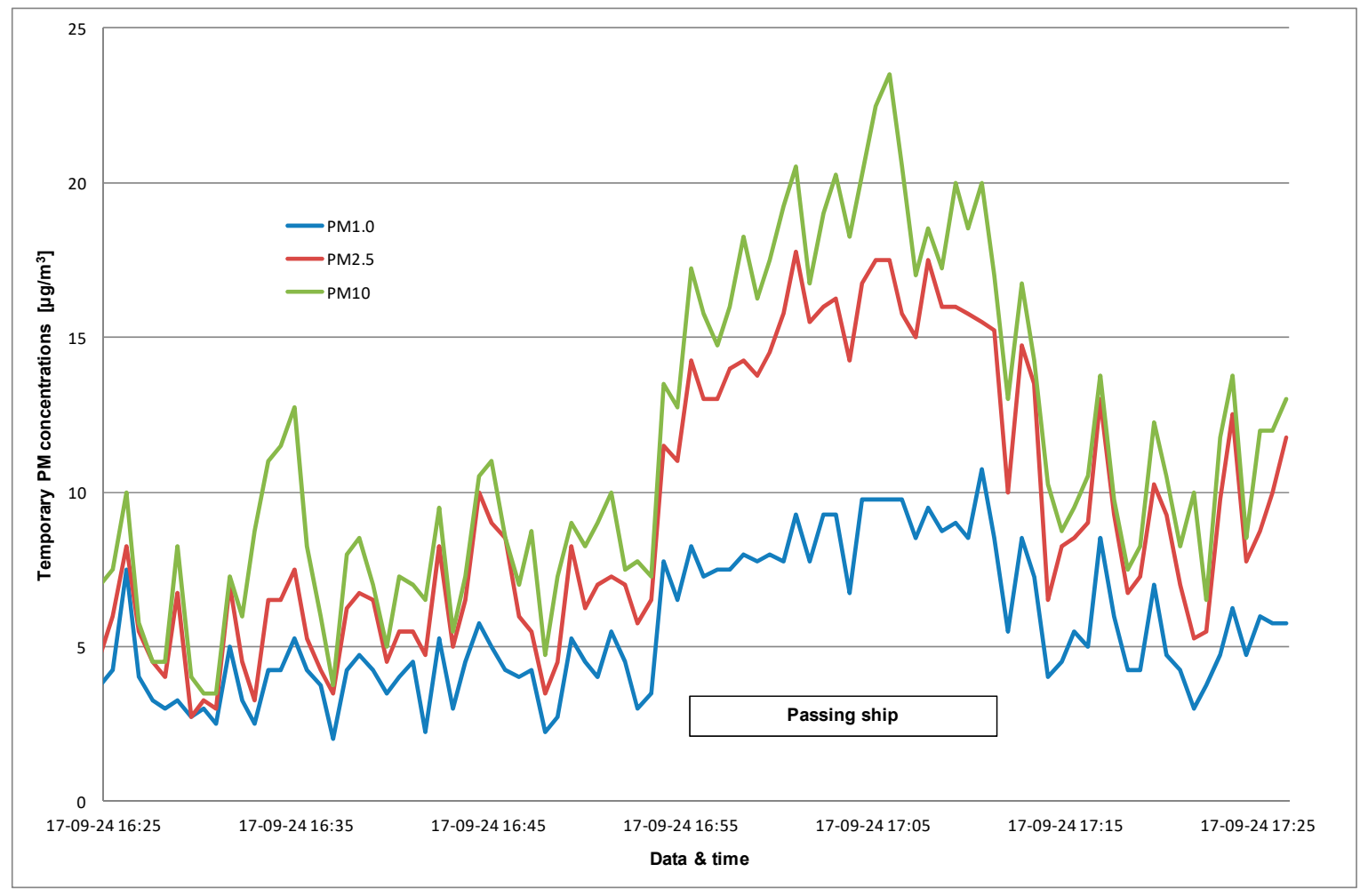

Figure 12. Temporary PM concentrations between 16:25 and 17:25 on 24 September 2017.

Before this meeting occurred, the average $1 \mathrm{~h}$ concentration of $\mathrm{PM}_{10}$ was about $6 \mu \mathrm{g} / \mathrm{m}^{3}$, while the $\mathrm{PM}_{2.5}$ concentration-about $4.5 \mu \mathrm{g} / \mathrm{m}^{3}$ (temporary maximum concentrations of $\mathrm{PM}_{10}$ were about $11-12 \mu \mathrm{g} / \mathrm{m}^{3}$, and $\mathrm{PM}_{2.5}$-approximately 9-10 $\left.\mu \mathrm{g} / \mathrm{m}^{3}\right)$. The presence of oil the tanker caused quite a rapid increase in the concentrations of $P_{10}$ to $23 \mu \mathrm{g} / \mathrm{m}^{3}$, and $\mathrm{PM}_{2.5}$ to $17.5 \mu \mathrm{g} / \mathrm{m}^{3}$. The increase lasted about $20 \mathrm{~min}$. At that time, the average $\mathrm{PM}_{10}$ concentration was close to $18 \mu \mathrm{g} / \mathrm{m}^{3}$, while $\mathrm{PM}_{2.5}-15 \mu \mathrm{g} / \mathrm{m}^{3}$ (Figure 12). The increase in particulate matter concentrations caused by the passing ship was about $12 \mu \mathrm{g} / \mathrm{m}^{3}\left(\mathrm{PM}_{10}\right)$ and $10.5 \mu \mathrm{g} / \mathrm{m}^{3}\left(\mathrm{PM}_{2.5}\right)$. After that, the level of particulate matter concentrations of all fractions dropped, but it was slightly higher than before the encounter. This was probably caused by the presence of exhaust gases from other ships.

The influence of oil tanker emission can also be confirmed by the fact that when passing and after, the share of $\mathrm{PM}_{2.5}$ fraction in the general PM concentration increased (Figure 13). The wind speed was about $5 \mathrm{~m} / \mathrm{s}$ and direction E (Figure 14a). Before this meeting, its share was approximately $70 \%$, while during and after it increased to approximately $85 \%$. Mainly the share of particles in the range $\mathrm{PM}_{2.5} \div \mathrm{PM}_{10}$ increased from approximately $25 \%$ to $35 \%$. A larger share of the finer PM fractions in total PM emission from ships using marine oil is demonstrated by [28,29]. The authors confirmed that practically all particulate matter coming from large-scale, marine diesel engines have sizes significantly lower than $2.5 \mu \mathrm{m}$, defined as $\mathrm{PM}_{2.5}$, and largely also finer than $1.0 \mu \mathrm{m}, \mathrm{PM}_{1}$. They also showed a number and particle size distribution for intermediate diesel engines based on the data of [30] along with pictures representing the different fractions of PM. The trimodal particle size distribution was observed with two maxima in the submicron range and a third one in the range higher than several microns. Similar observations were made in [31], showing that the mass particle size distribution had 
a bimodal shape with two peaks, one in the accumulation mode at particle diameter about $0.5 \mu \mathrm{m}$ and one in the coarse mode at particle diameter around $7 \mu \mathrm{m}$.

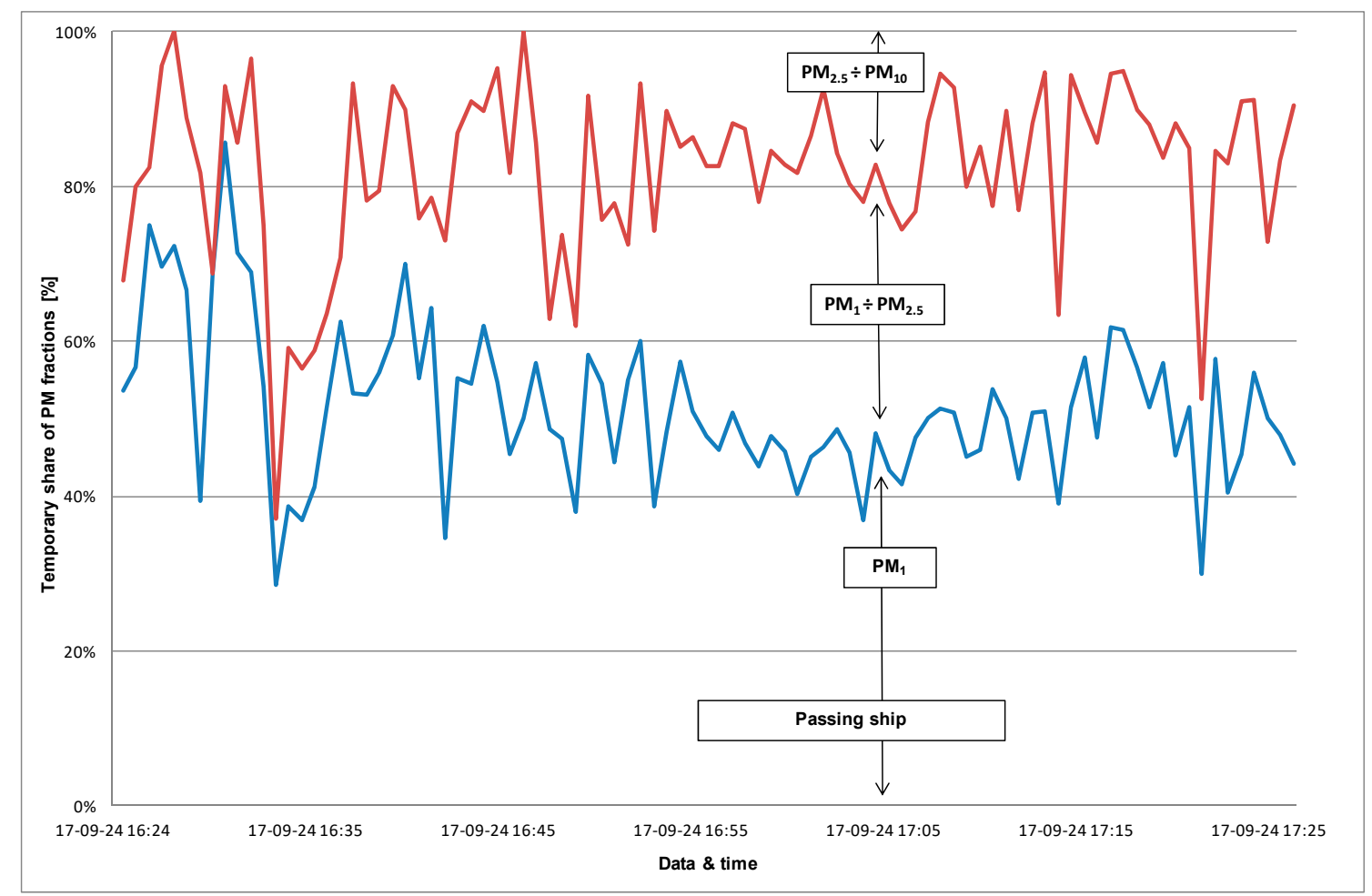

Figure 13. Temporary share of fractions PM between 16:25 and 17:25 on 24 September 2017.

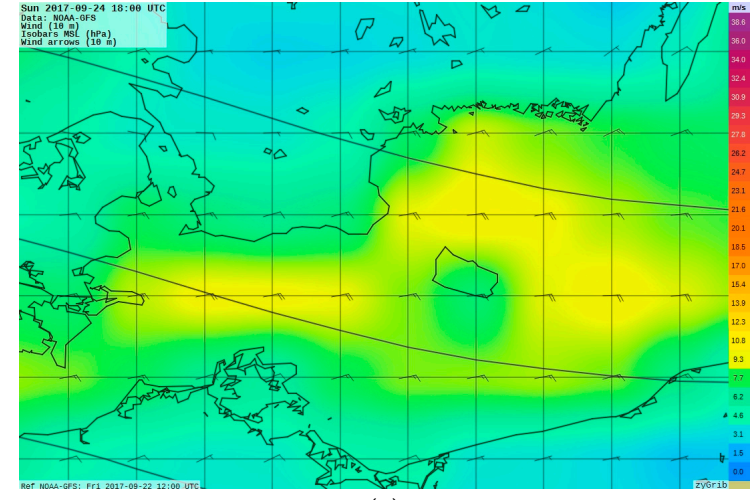

(a)

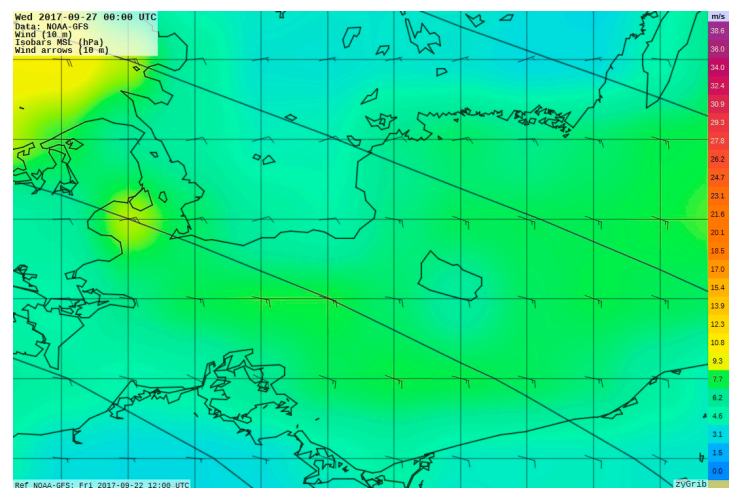

(b)

Figure 14. Forecast of wind strength and direction at 18:00 on 24 September 2017 (a) and at 00:00 on 27 September 2017 (b) based on NOAA-GTS data from 12:00 on 22 September 2017.

Similar character of air pollution change can be spotted on 27 September 2017 between 02:00 and 03:00 (Figure 15). The tall ship was then $25 \mathrm{~km}$ from the nearest land (direction SW), so much further than during the past hours of cruise. The average wind speed was around $7 \mathrm{~m} / \mathrm{s}$ direction ESE (Figure 14b). The distance to the land in the direction of the blowing wind was over $180 \mathrm{~km}$, so it is unlikely that the pollutants were coming from the land. The tall ship was doing sailing manoeuvre near to the main shipping lane and changing its direction. The jibe takes in case of the tall ship almost $1 \mathrm{~h}$.

Before the maneuver, the average concentrations were about $18 \mu \mathrm{g} / \mathrm{m}^{3}\left(\mathrm{PM}_{10}\right)$ and $13 \mu \mathrm{g} / \mathrm{m}^{3}$ $\left(\mathrm{PM}_{2.5}\right)$. Passing of ship at 02:30, lasting about $6 \mathrm{~min}$, caused a short-term increase in concentrations to approximately $46 \mu \mathrm{g} / \mathrm{m}^{3}\left(\mathrm{PM}_{10}\right)$ and $38 \mu \mathrm{g} / \mathrm{m}^{3}\left(\mathrm{PM}_{2.5}\right)$-Figure 15 . The time of concentration increase was shorter than in the first case, because the tall ship was changing sailing direction and not moving 
in the same direction as the passing ship. The value of $\mathrm{PM}_{10}$ equal to $51 \mu \mathrm{g} / \mathrm{m}^{3}$ was the highest during the whole two-week cruise.

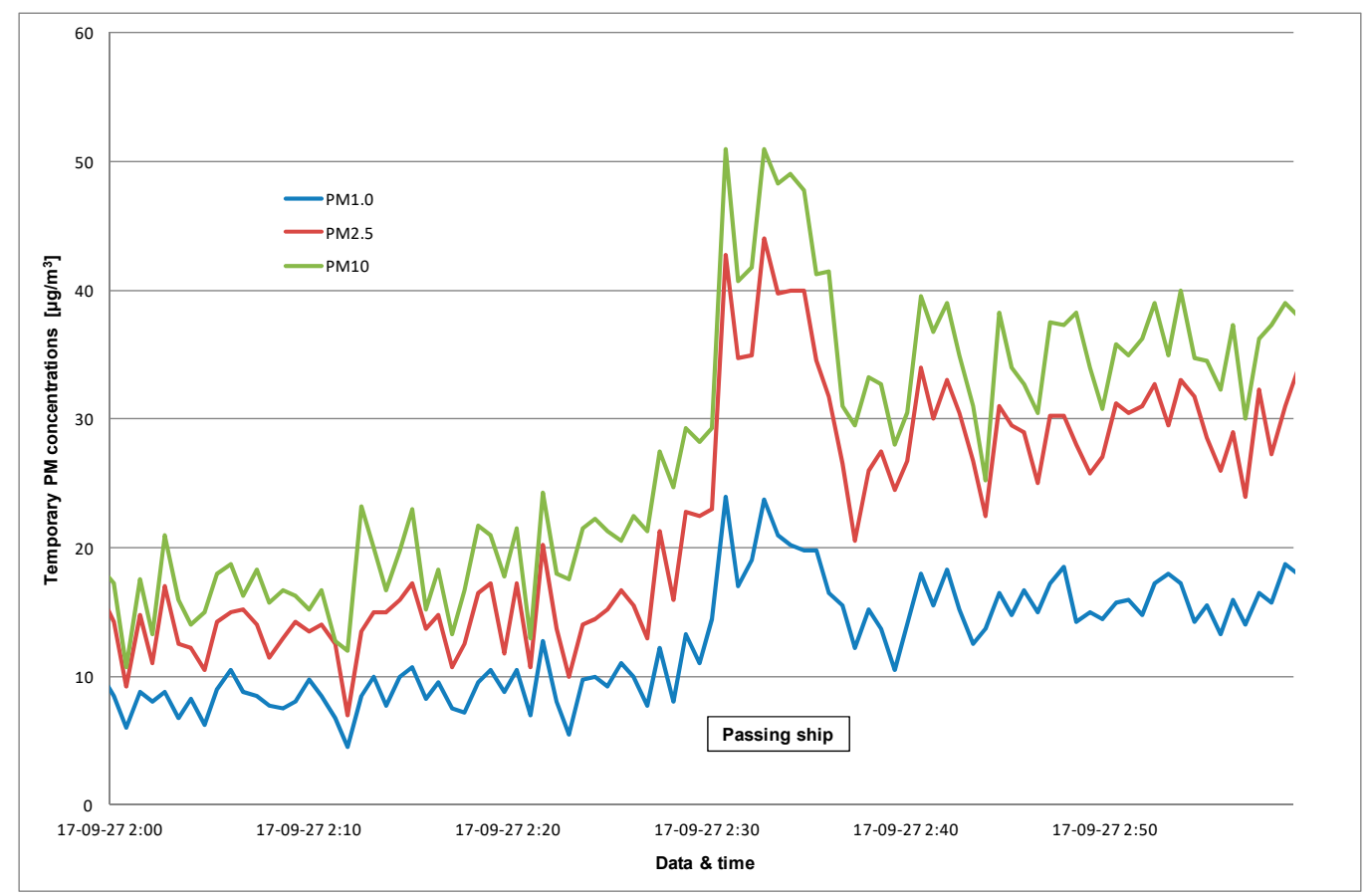

Figure 15. Temporary PM concentrations between 02:00 and 03:00 on 27 September 2017.

Also in this case, with the increase in concentrations, the share of PM fractions changed (Figure 16). Before the meeting, $\mathrm{PM}_{2.5}$ in $\mathrm{PM}_{10}$ was about $72 \%$, while during passing and later-over $82 \%$. Mainly the share of particles in the range $\mathrm{PM}_{2.5} \div \mathrm{PM}_{10}$ increased from approximately $30 \%$ to $38 \%$. The increase in the $P M$ concentrations caused by the passing ship was about $28 \mu \mathrm{g} / \mathrm{m}^{3}$ for $\mathrm{PM}_{10}$ and $25 \mu \mathrm{g} / \mathrm{m}^{3}$ for $\mathrm{PM}_{2.5}$. After passing, the concentrations slightly decreased, but were still higher than before. This can be caused by the manoeuvre, during which the position of the ship is not changing a lot, only its direction. The wind direction ESE was appropriate to allow the migration of pollutants from near the located shipping lane. As it moves away from it, the concentration of particles was decreasing (Figure 15).

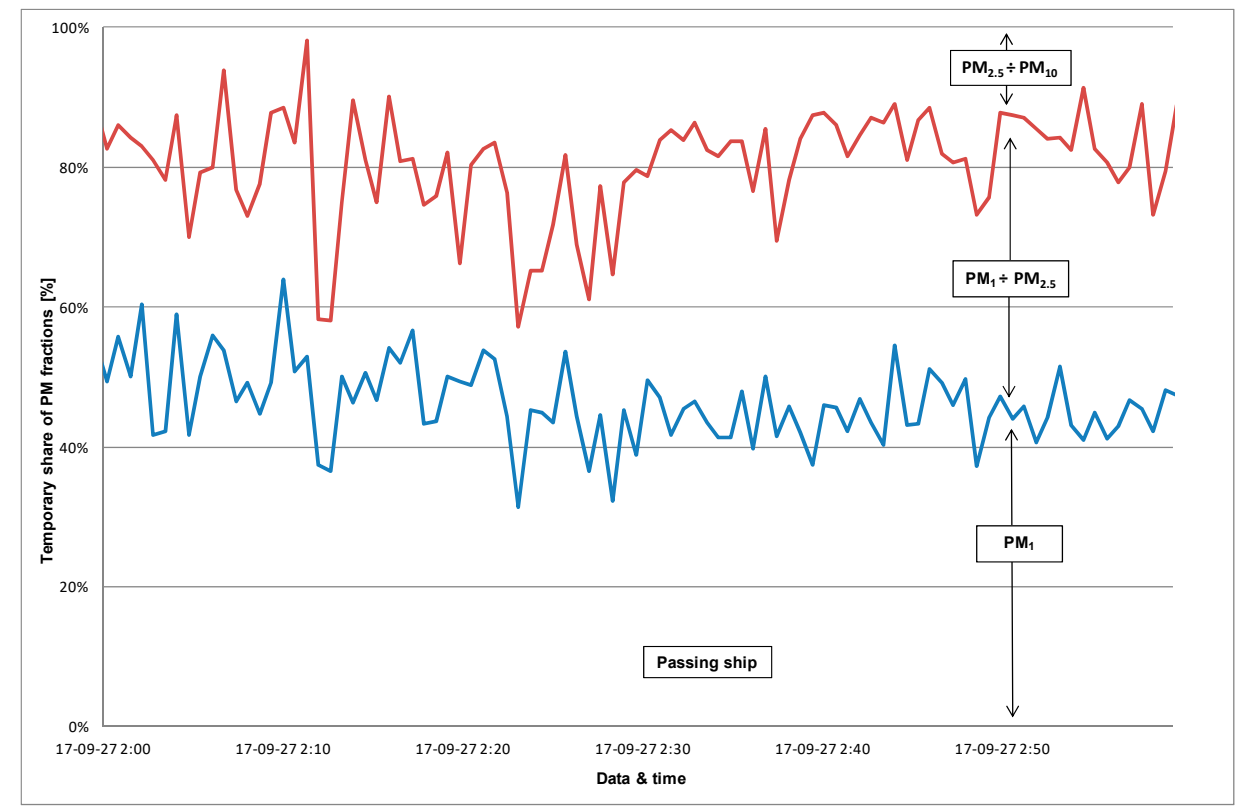

Figure 16. Temporary share of fractions PM between 02:00 and 03:00 on 27 September 2017. 
The measurement results show the visible impacts of marine traffic on air pollution. The main emission sources are the cargo and passenger ships. Their average fuel consumption [29] is from 21 to $70 \mathrm{Mg} /$ day depending on ship type and speed. The PM emission in cruising mode is from 1.2 to $7.6 \mathrm{~kg} / \mathrm{Mg}$ of fuel depending on the engine type. The estimated PM emission from one ship can be between 25.2 and $532.0 \mathrm{~kg}$ per day. This can be compared to emission from a single-family building using an oil boiler which is around $0.9 \mathrm{~kg}$ per year [32]. One ship emits per day as much as 30-600 houses per year. More detailed information about shipping emissions can be found in [33].

\section{Conclusions}

The air pollution from ships continues to grow as the international shipping sector increases. Scientific studies [34] show that air pollution from the sector can be responsible for 50,000 premature deaths yearly in Europe. The shipping-related PM emissions can be responsible for approximately 60,000 cardiopulmonary and lung cancer deaths every year, with most deaths occurring close to coastlines in Europe, East Asia, and South Asia [35]. According to the Authors, the annual mortality rate associated to this will increase in the next years. Therefore, it is crucial to determine suitable solutions for sustainable sea transport. Current policy discussions (e.g., carried out within The European Sustainable Shipping Forum) aimed at decreasing air pollution from ships are focused on two concerns [35]:

- the implementation of international instruments regulating/addressing pollutants emissions from ships;

- the benefits and cost-effectiveness of various emission-reduction strategies.

Numerous researchers are working on solutions like fuels containing a lower level of sulfur and lower amount of higher carbon molecules, combustion process modification and flue-gas treatment. Another solution could be adoption of a dual-fuel engine or use of various renewable energies, e.g., wind harnessed by sails, kites, and rotors [36].

The research carried out during the cruise of the tall ship (using wind energy) gave the possibility to measure the concentration of suspended particles $\left(\mathrm{PM}_{1}, \mathrm{PM}_{2.5}\right.$, and $\left.\mathrm{PM}_{10}\right)$ on the North and Baltic seas, in the ports, as well as determination of the PM concentration increase caused by the passing ships. The ship's own pollutants emission was minimized, due to the use of sails as the main drive. Also, the ship's cruise had covered areas with both a high and small intensity of maritime traffic. Thanks to this, a big variability of data was collected and analyzed. Results show that there is a visible difference in the air pollution between the area of the North Sea-starting from the Scottish coast up to Danish or Swedish coasts and the Baltic Sea. Much higher level of PM concentrations was found in this basin in comparison to the North Sea, or even the Copenhagen port- $1 \mathrm{~h}$ average $\mathrm{PM}_{10}$ concentration close to $40 \mu \mathrm{g} / \mathrm{m}^{3}$, for individual measurements: $51 \mu \mathrm{g} / \mathrm{m}^{3} \mathrm{PM}_{10}$ and $44 \mu \mathrm{g} / \mathrm{m}^{3} \mathrm{PM}_{2.5}$. For comparison, $1 \mathrm{~h}$ average $\mathrm{PM}_{10}$ concentration below $5 \mu \mathrm{g} / \mathrm{m}^{3}$ was recorded in the area of Edinburgh. There was also an increase in PM concentration in places where there were frequented shipping routes (both in the North Sea and in the Baltic Sea).

The undertaken analysis of pollution migration, in regard to the distance to the land (in the direction of the blowing wind), has shown two areas of high $\mathrm{PM}_{10}$ concentration. The first one covered a distance from 0 to about $90 \mathrm{~km}$. In this case, the high level of particulate matter concentration was probably caused by land sources, located in ports or cities. This was confirmed by the observed cycle of concentration changes which adopted evident "land" characteristics. Another source of emissions could be marine traffic especially in such places where the main shipping lanes are close to the land. The second area of high concentration was spotted in the distance from 140 to $220 \mathrm{~km}$ from the land. It seems that, in this case, the emissions arising from ships dominated. The highest concentrations were measured at a considerable distance from land, where the influence of land-based emission sources is rather negligible. The precise analysis of PM concentrations changes confirmed this thesis. 
During the cruise fieldwork research, it was possible to identify at least two places where passing ships caused a visible increase of PM concentration. The increase in the PM concentrations caused by the passing ship was about $18-28 \mu \mathrm{g} / \mathrm{m}^{3}$ for $\mathrm{PM}_{10}$ and $15-25 \mu \mathrm{g} / \mathrm{m}^{3}$ for $\mathrm{PM}_{2.5}$. The share of $\mathrm{PM}_{2.5}$ fraction in the general PM concentration increased from $70-72 \%$ to $82-85 \%$. Additionally, the share of particles in the range $\mathrm{PM}_{2.5} \div \mathrm{PM}_{10}$ increased from approximately $25-30 \%$ to $35-38 \%$. This confirms that combustion emission, coming from marine diesel engines, dominated. The pollution from the ships can cause relatively high PM concentrations, also of land areas, where there are many more emission sources (as in the Baltic Sea example). In [37], authors concluded that shipping emissions contribute with $1-7 \%$ to annual mean $\mathrm{PM}_{10}$ levels, with $1-20 \%$ to $\mathrm{PM}_{2.5}$, and with $8-11 \%$ to $\mathrm{PM}_{1}$ in the Mediterranean basin and the North Sea. However, in the case of the Baltic Sea, this contribution may be larger. The significantly higher, measured level of pollution in this basin compared to concentrations in the North Sea could confirm it. Our prospected further research will focus on this element.

Author Contributions: Conceptualization, S.F. methodology, M.R.; software, M.R.; validation, M.R.; formal analysis, S.F.; investigation, S.F.; resources, M.R.; data curation, M.R.; writing-original draft preparation, S.F.; writing-review and editing, S.F.; visualization, S.F.; supervision, A.B.; project administration, S.F.

Funding: This research received no external funding.

Acknowledgments: We gratefully thank Captain Bartłomiej Skwara for the support.

Conflicts of Interest: The authors declare no conflict of interest.

\section{References}

1. European Commission (EC). Air Quality Standards. Available online: http://ec.europa.eu/environment/ air/quality/standards.htm (accessed on 7 March 2018).

2. European Environment Agency (EEA). Air Quality in Europe-2014 Report; Report No. 5/2014; EEA: Copenhagen, Denmark, 2014.

3. Majewski, G.; Badyda, A.; Czechowski, P.O.; Dabrowiecki, P.; Gayer, A.; Mucha, D.; Adamkiewicz, L. The Prevalence of Selected Respiratory Diseases and the Exposure to $\mathrm{PM}_{10}$ in the Ambient Air. AST J. 2016, 193, A5417.

4. Majewski, G.; Badyda, A.; Gayer, A.; Czechowski, P.O.; Dabrowiecki, P. Pulmonary Function and Incidence of Selected Respiratory Diseases Depending on the Exposure to Ambient PM10. Int. J. Mol. Sci. 2016, 17, 1954. [CrossRef]

5. World Health Organization (WHO). Health Risks of Air Pollution in Europe-HRAPIE Project: Recommendations for Concentration-Response Functions for Cost-benefit Analysis of Particulate Matter, Ozone and Nitrogen Dioxide; Report of WHO Regional Office for Europe; WHO Regional Office for Europe: Copenhagen, Denmark, 2013.

6. Heimann, I.; Bright, V.B.; McLeod, M.W.; Mead, M.I.; Popoola, O.A.M.; Stewart, G.B.; Jones, R.L. Source attribution of air pollution by spatial scale separation using high spatial density networks of low cost air quality sensors. Atmos. Environ. 2015, 113, 10-19. [CrossRef]

7. Van den Bossche, J.; Peter, J.; Verwaeren, J.; Botteldooren, D.; Theunis, J.; De Baets, B. Mobile monitoring for mapping spatial variation in urban air quality: Development and validation of a methodology based on an extensive dataset. Atmos. Environ. 2015, 105, 148-161. [CrossRef]

8. Wong, M.S.; Wang, T.; Ho, H.C.; Kwok, C.Y.T.; Lu, K.; Abbas, S. Towards a Smart City: Development and Application of an Improved Integrated Environmental Monitoring System. Sustainability 2018, 10, 623. [CrossRef]

9. Han, L.; Zhou, W.; Li, W. Growing Urbanization and the Impact on Fine Particulate Matter (PM2.5) Dynamics. Sustainability 2018, 10, 1696. [CrossRef]

10. Ma, Y.; Richards, M.; Ghanem, M.; Guo, Y.; Hassard, J. Air Pollution Monitoring and Mining Based on Sensor Grid in London. Sensors 2008, 8, 3601-3623. [CrossRef] [PubMed]

11. Kumar, P.; Morawska, L.; Martani, C.; Biskos, G.; Neophytou, M.; Di Sabatino, S.; Bell, M.; Norford, L.; Britter, R. The rise of microsensing for managing air pollution in cities. Environ. Int. 2015, 75, 199-205. [CrossRef] [PubMed] 
12. Snyder, E.; Watkins, T.; Solomon, P.; Thoma, E.; Williams, R.; Hagler, G.; Shelow, D.; Hindin, D.; Kilaru, V.; Preuss, P. The changing paradigm of air pollution monitoring. Environ. Sci. Technol. 2013, 47, 11369-11377. [CrossRef] [PubMed]

13. Bove, M.C.; Brotto, P.; Calzolai, G.; Cassola, F.; Cavalli, F.; Fermo, P.; Hjorth, J.; Massabò, D.; Nava, S.; Piazzalunga, A.; et al. $\mathrm{PM}_{10}$ source apportionment applying PMF and chemical tracer analysis to ship-borne measurements in the Western Mediterranean. Atmos. Environ. 2016, 125, 140-151. [CrossRef]

14. Schembari, C.; Bove, M.C.; Cuccia, E.; Cavalli, F.; Hjorth, J.; Massab, D.; Nava, S.; Udisti, R.; Prati, P. Source apportionment of $\mathrm{PM}_{10}$ in the Western Mediterranean based on observations from a cruise ship. Atmos. Environ. 2014, 98, 510-518. [CrossRef]

15. Romagnoli, P.; Balducci, C.; Perilli, M.; Perreca, E.; Cecinato, A. Particulate PAHs and n-alkanes in the air over Southern and Eastern Mediterranean Sea. Chemosphere 2016, 159, 516-525. [CrossRef] [PubMed]

16. Deniz, C.; Kilic, A.; Civkaroglu, G. Estimation of shipping emissions in Candarli Gulf, Turkey. Environ. Monit. Assess. 2010, 171, 219-228. [CrossRef] [PubMed]

17. Yau, P.S.; Lee, S.C.; Corbett, J.J.; Wang, C.; Cheng, Y.; Ho, K.F. Estimation of exhaust emission from ocean-going vessels in Hong Kong. Sci. Total Environ. 2012, 431, 299-306. [CrossRef] [PubMed]

18. Chen, D.; Wang, X.; Li, Y.; Lang, J.; Zhoua, Y.; Guo, X.; Zhao, Y. High-spatiotemporal-resolution ship emission inventory of China based on AIS data in 2014. Sci. Total Environ. 2017, 609, 776-787. [CrossRef] [PubMed]

19. Zhang, Z.; Yang, X.; Brown, R.; Yang, L.; Morawska, L.; Ristovski, Z.; Fu, Q.; Huang, C. Shipping emissions and their impacts on air quality in China. Sci. Total Environ. 2017, 581, 186-198. [CrossRef] [PubMed]

20. Liu, H.; Jin, X.; Wu, L.; Wang, X.; Fu, M.; Lv, Z.; Morawska, L.; Huang, F.; Hea, K. The impact of marine shipping and its DECA control on air quality in the Pearl River Delta, China. Sci. Total Environ. 2018, 625, 1476-1485. [CrossRef] [PubMed]

21. Rogulski, M. The use of low-cost measuring devices for testing air quality in hard-to-reach locations. Energy Proc. 2017, 128, 437-444. [CrossRef]

22. Rogulski, M. Using low-cost PM monitors to detect local changes of air quality. Pol. J. Environ. Stud. 2018, 27. accepted. [CrossRef]

23. Isaac, M. Regulatory considerations of lower cost air pollution sensor data performance. Environ. Manag. 2014, 7, 32-37. [CrossRef]

24. Gao, M.; Cao, J.; Seto, E. A distributed network of low-cost continuous reading sensors to measure spatiotemporal variations of PM2.5 in Xi'an, China. Environ. Pollut. 2015, 199, 56-65. [CrossRef] [PubMed]

25. Crilley, L.R.; Shaw, M.; Pound, R.; Kramer, L.J.; Price, R.; Young, S.; Lewis, A.C.; Pope, F.D. Evaluation of a low-cost optical particle counter (Alphasense OPC-N2) for ambient air monitoring. Atmos. Meas. Tech. 2018, 11, 709-720. [CrossRef]

26. Scotland Air Quality Data and Statistics Database, Particulate Matter $\left(P M_{10}\right)$ Concentrations $\left(\mu g / m^{3}\right) ;$ Scottish Government: Edinburgh, UK, 2016.

27. Eyring, V.; Isaksen, I.S.A.; Berntsen, T.; Collins, W.J.; Corbett, J.J.; Endresen, O.; Grainger, R.G.; Moldanova, J.; Schlager, H.; Stevenson, D.S. Transport impacts on atmosphere and climate: Shipping. Atmos. Environ. 2010, 44, 4735-4771. [CrossRef]

28. Di Natale, F.; Carotenuto, C. Particulate matter in marine diesel engines exhausts: Emissions and control strategies. Transp. Res. Part D Transp. Environ. 2015, 40, 166-191. [CrossRef]

29. Sarvi, A.; Lyyränen, J.; Jokiniemi, J.; Zevenhoven, R. Particulate emissions from large-scale medium-speed diesel engines: 1. Particle size distribution. Fuel Process. Technol. 2011, 92, 1855-1861. [CrossRef]

30. Fridell, E.; Steen, E.; Peterson, K. Primary particles in ship emissions. Atmos. Environ. 2008, 42, 1160-1168. [CrossRef]

31. Moldanova, J.; Fridell, E.; Popovicheva, O.; Demirdjian, B.; Tishkova, V.; Faccinetto, A.; Focsa, C. Characterisation of particulate matter and gaseous emissions from a large ship diesel engine. Atmos. Environ. 2009, 43, 2632-2641. [CrossRef]

32. Firlag, S. How to meet the minimum energy performance requirements of Technical Conditions in year 2021? Procedia Eng. 2015, 111, 202-208. [CrossRef]

33. Deniz, C.; Durmuşoğlu, Y. Estimating shipping emissions in the region of the Sea of Marmara, Turkey. Sci. Total Environ. 2008, 390, 255-261. [CrossRef] [PubMed] 
34. Brandt, J.; Silver, J.D.; Heile Christensen, J.; Skou Andersen, M.; Geels, C.; Gross, A.; Buus Hansen, A.; Mantzius Hansen, K.; Brandt Hedegaard, G.; Ambelas Skjøth, C. Assessment of Health-Cost Externalities of Air Pollution at the National Level Using the EVA Model System; Centre for Energy, Environment and Health Report Series; University of Copenhagen: Copenhagen, Denmark, 2011; ISSN 1904-7495.

35. Corbett, J.J.; Winebrake, J.J.; Green, E.H.; Kasibhatla, P.; Eyring, V.; Lauer, A. Mortality from Ship Emissions: A Global Assessment. Environ. Sci. Technol. 2007, 41, 8512-8518. [CrossRef] [PubMed]

36. Nuttall, P.; Newell, A.; Prasad, B.; Veitayaki, J.; Holland, E. A review of sustainable sea-transport for Oceania: Providing context for renewable energy shipping for the Pacific. Mar. Policy 2014, 283-287. [CrossRef]

37. Viana, M.; Hammingh, P.; Colette, A.; Querol, X.; Degraeuwe, B.; de Vlieger, I. Impact of maritime transport emissions on coastal air quality in Europe. Atmos. Environ. 2014, 9, 96-105. [CrossRef]

2018 by the authors. Licensee MDPI, Basel, Switzerland. This article is an open access article distributed under the terms and conditions of the Creative Commons Attribution (CC BY) license (http:/ / creativecommons.org/licenses/by/4.0/). 